Anaesthesist 2018 $67: 426-447$

https://doi.org/10.1007/s00101-018-0445-2

Revised: 8 April 2018

Accepted: 11 April 2018

Published online: 15 May 2018

(c) Springer Medizin Verlag GmbH, ein Teil von

Springer Nature 2018

CrossMark
Received: 9 February 2018

\author{
I. Kezze $\cdot$ N. Zoremba ${ }^{2} \cdot$ R. Rossaint ${ }^{1} \cdot$ A. Rieg ${ }^{1} \cdot$ M. Coburn ${ }^{1} \cdot$ G. Schälte ${ }^{1}$ \\ 'Department of Anesthesiology, University Hospital RWTH Aachen, Aachen, Germany \\ ${ }^{2}$ Department of Anesthesiology, Critical Care and Emergency Medicine, St. Elisabeth Hospital Gütersloh, \\ Gütersloh, Germany
}

\section{Risks and prevention of surgical fires}

\section{A systematic review}

\section{Introduction}

A surgical fire is an expression that arouses many questions; however, individuals are unlikely to consider potential procedural operation risks. A surgical fire is a rare complication that occurs in operation theatres worldwide and is often considered one of the few surgical 'never events', such as wrong-site surgery or retained surgical items [1]. Hence, a vast number of surgeons and anesthesiologists are unaware of this intraoperative risk. In the USA, the prevalence of surgical fires has been estimated at approximately 600 events per year, which make us question if it is possible to even consider it one of the "never events". Since there are no reporting regulations or a formal critical incident reporting system, the total number of events is probably underestimated [2].

A surgical fire is a fire that occurs either in the patient themselves, e.g., in the trachea or respiratory tract or on the patient's skin, explaining the inevitable life-threatening burns and associated in-

\section{Authors' contributions}

$\mathrm{IK}, \mathrm{NZ}$, GS: primary literature search; IK, AR, GS: secondary literature survey and appraisal; IK, GS, MC statistical analysis; IK, NZ and GS: interpretation of data and results, IK drafted the manuscript; NZ, RR, GS and MC corrected the manuscript; RR: final approval; GS: idea and supervision

All authors gratefully acknowledge and appreciate the statistical advice in methodology, interpretation of the results and final soundness provided by the Department of Medical Statistics, RWTH Aachen University, Faculty of Medicine, Aachen, Germany. juries [3]. This is precisely the result in many cases where the endotracheal tube ignites like a blowtorch, causing severe damage to the airway and lungs [4]. To ignite a fire, only 3 factors must coincide and these circumstances are referred to in the literature as the "fire triad", which consists of an oxidizer, an ignition source and a fuel [3]. This particular composition is mainly located in narrow spaces with low circulation, "trapping" air and volatile chemicals during the operation. These spaces are most likely to be found in the neck-nose-throat area; most of the surgical fire reports indicate that $25 \%$ are associated with otorhinolaryngological interventions [5].

This systematic review aims to call attention to this underestimated intraoperative risk and to determine the impact of each component of the fire triad. Moreover, we aim to raise surgical staff awareness to this hazard and thus prevent a surgical fire or in an unpreventable case, encourage them to react fast and to correctly protect the patient from major life-threatening injuries.

\section{Inclusion criteria}

Current scientific research on surgical fires has insufficient data with little scientific evidence. Due to the risk of injury and harm, no randomized controlled trials are available. Therefore, we strived to include prospective experimental laboratory and manikin trials, particularly those with a control group. Case reports and case series with precise event descriptions were also reviewed separately in order to analyze and summarize the fire causes.

A literature search was conducted by screening PubMed, Livivo (Medline) and Google Scholar using various search terms, keywords and combinations. These search terms included, "Surgical Fire", "Airway Fire", "Fire in the OR", "Fire Hazard", "Fire Triangle", "Fire Triad", "Oxygen-enriched Environment", "Fire Surgical Drape", "Oxygen Pooling", "Fire Supplemental Oxygen", "Fire Prevention", "Fire Protection", "Fire Safety", "Fire Electrocautery", "Fire Electrocoagulation", "Fire Laser", and "Fire Skin Preparation".

\section{Risk of bias}

With the risk of bias in non-randomized studies (ROBINS-I) tool, developed by members of the Cochrane Bias Methods Group and the Cochrane Non-Randomized Studies Methods Group, the statistical bias potential was collated and evaluated.

\section{Statistics and limitations}

The aim of the systematic search was a quantitative synthesis, according to the PRISMA search criteria and checklist (๑ Fig. 1). After the data were extracted ware (Review Manager, Version 5.3., The Nordic Cochrane Centre, The Cochrane Collaboration, Copenhagen, Denmark),

\section{Sources of information} and summarized through RevMan soft- 


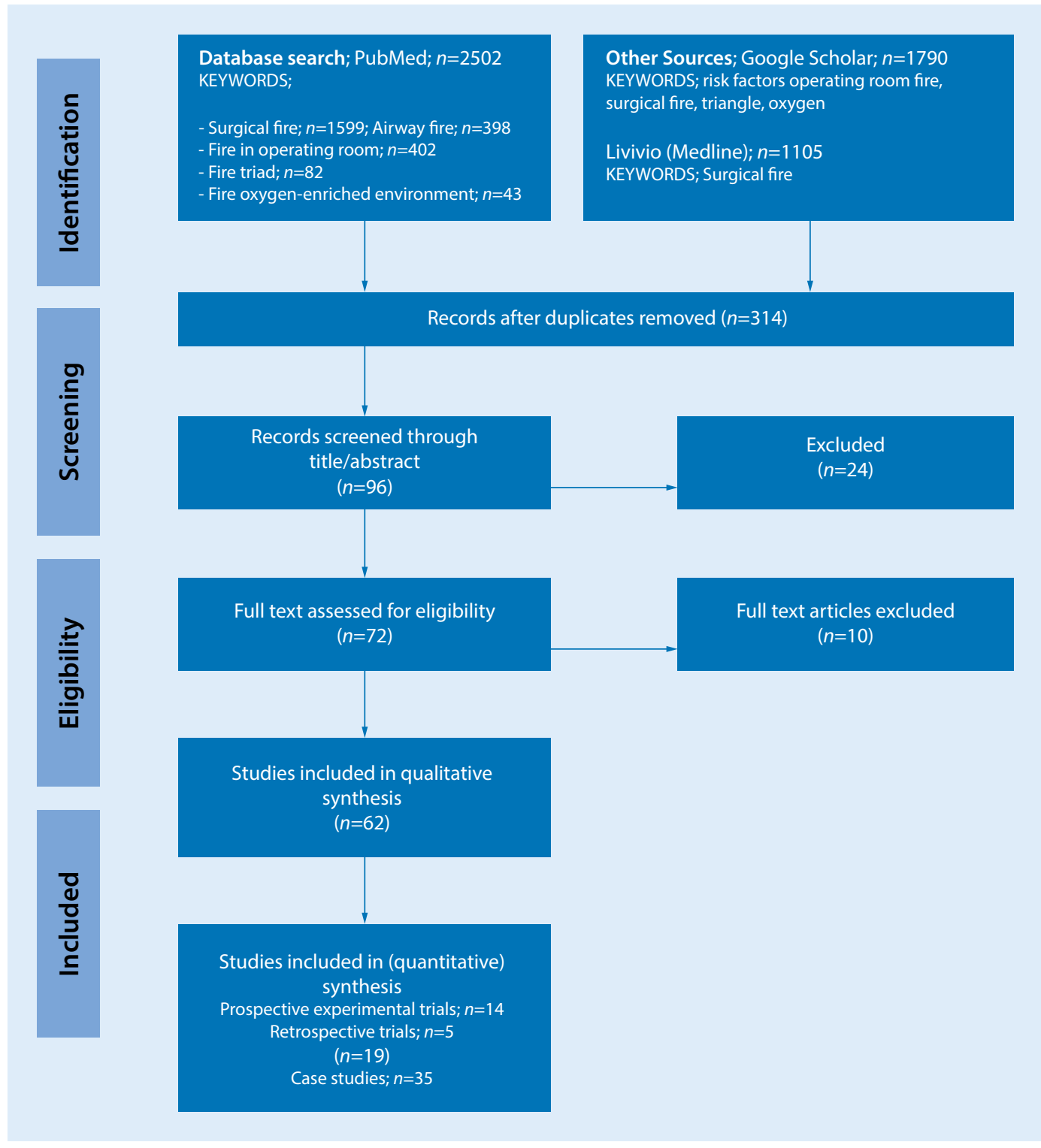

Fig. $1<$ PRISMA flowchart of the systematic research process

the preliminary results were presented and discussed at the Department of Biomedical Statistics of the RWTH Aachen University, Aachen, Germany.

It was advised that due to the lack of randomized controlled trials, the studies finally included should not be summarized in a meta-analysis. Statistically relevant information and experiments often differed regarding various study parameters:

- Test object: human versus animal versus textile or plastic,

- Number of cases versus dichotomous events,

- Lack of statistically relevant information: inter alia, $P$ value, standard deviation,
- Group comparisons: experimental group versus control group or experimental versus experimental,

- Trial findings: fire versus fire risk.

Therefore, the context of all studies is comprehensively outlined by either a description or summary in tables. Additionally, the particular roles of oxidizers, fuel and ignition sources are evaluated.

\section{Results}

\section{Risk of bias}

Overall, the risk of bias result demonstrated a moderate risk for the observational trials (-Table 1). Almost ev- ery trial was conducted by assessors who were not blinded to the trial, which complicates the chance of not having any bias through the measurements and outcomes. Additionally, numerous experiments were performed only once for each condition, which creates bias due to highly probable random errors.

Most of the studies included were prospective, implicating a low risk of bias as a result of no confounding variables and classification of/deviation from the intervention. Moderate risk means that the studies provide sound evidence for non-randomized studies but cannot be considered comparable to wellperformed randomized trials and there- 
Anaesthesist 2018 -67:426-447 https://doi.org/10.1007/s00101-018-0445-2

(c) Springer Medizin Verlag GmbH, ein Teil von Springer Nature 2018

I. Kezze · N. Zoremba · R. Rossaint · A. Rieg · M. Coburn · G. Schälte

Risks and prevention of surgical fires. A systematic review

\section{Abstract}

Surgically induced fire is a life-threatening hazard; this topic has received little attention, although only 3 factors, the so-called fire triad, are needed for surgical fires to occur: an oxidizer, fuel and an ignition source. This systematic review aims to determine the impact of each component and to delegate every staff member an area of responsibility, thus ensuring patient health through prevention or protection. The trial was registered in Prospero CRD42018082656. A database search of eligible, preferably evidence-based studies was conducted. The Robins-I tool for assessing the risk of bias revealed a moderate risk of bias. Due to insufficient data, the main findings of these studies could not be summarized through a quantitative synthesis; therefore, a qualitative synthesis is outlined. The results are summarized according to the roles of the fire triad and discussed. (1) Role of the oxidizer: oxygen is the key component of the triad. Safe oxygen delivery is important. An oxygen-enriched environment (ORE) is caused by draping and is preferably prevented by suctioning. Fuel characteristics are affected by varying oxygen concentrations. (2) Role of the ignition source: electrocauterization is the most common ignition source, followed by lasers. Less common ignition sources include fiberoptic cables and preparative solutions, petrol or acetone. (3) Role of the fuel: surgical drapes are one of the most common fuels for surgical fires followed by the patient's hair and skin. Skin preparation solutions are among the less common fuels. Many fireresistant materials have been tested that do not remain fire resistant in ORE. It was concluded that the main problem is defining the real extent of this hazard. Exact numbers and exact condition protocols are needed; therefore, standardized registration of every fire and future studies with much evidence are needed. Immediate prevention consists of close attention to patient safety to prevent surgical fires from happening.

\section{Keywords}

Fire $\cdot$ Operation $\cdot$ Ignition source $\cdot$ Oxygen . Prevention

\section{Risiken und Prävention chirurgisch induzierter Feuer. Eine systematische Übersicht}

\section{Zusammenfassung}

Chirurgisch induzierte Feuer im Operationssaal sind eine für den Patienten in der Regel lebensbedrohliche Komplikation, die in der subjektiven Wahrnehmung aller an einer Operation beteiligten Personen eher vernachlässigt und nicht als aktives Risiko wahrgenommen wird. Dabei bedarf es zur Entstehung eines Feuers nur 3 paralleler Faktoren: Oxidans, Brennstoff und Zündquelle, zusammengefasst als die Feuertriade. Ziel dieser systematischen Übersichtsarbeit sind die Analyse und Bewertung jeder einzelnen Komponente des Verbrennungsdreiecks und deren Einordnung in den Berufsgruppen spezifischen Kontext, mit einer Festschreibung von Verantwortlichkeiten und dem gemeinsamen Ziel der Prävention. Die Studie wurde in Prospero (CRD42018082656) registriert. Dazu wurden verschiedene Datenbanken systematisch nach möglichst hoher Evidenz durchsucht sowie die "Treffer" analysiert und bewertet. Das Risiko einer Verzerrung wurde mit "moderat" (Robins-I-Modell) bewertet. Bedingt durch eine unzureichende Datenqualität (keine prospektiven randomisierten Studien, Tiermodelle, Kohorten und Fallberichte/-serien) verbot sich eine quantitative Synthese der Daten. Aus diesem Grund werden die Ergebnisse qualitativedeskriptiv sowie in zusammenfassenden Tabellen und Diagrammen dargestellt. Die Ergebnisse wurden in Analogie zu ihrer Rolle in einem Verbrennungsdreieck wie folgt zusammengefasst und bewertet. (1) Oxidationsmittel: Sauerstoff ist die Schlüsselkomponente im Verbrennungsdreieck. Die Applikation von Sauerstoff bedarf hoher Sicherheitsstandards. Die Entstehung einer sauerstoffangereicherten Umgebung, verursacht beispielsweise durch Abdecktücher, kann durch die präventive Installation einer adäquaten Absaugvorrichtung verhindert werden. Die Charakteristika potenzieller Brennstoffe sind abhängig von der lokalen Sauerstoffkonzentration. (2) Zündquelle: Die Elektrokoagulation stellt, gefolgt von Lasern, die häufigste Zündquelle dar. Seltener ist der Zündvorgang durch fiberoptische Leitungen oder die Selbstentzündung von Desinfektionsmitteln und Benzin oder Aceton getriggert. (3) Brennstoffe: Abdecktücher aller Art sind der "Haupttreibstoff" chirurgischer
Feuer, gefolgt von Körperbehaarung und Haut der Patienten. Seltenere Brennstoffe sind Hautdesinfektionsmittel und Reinigungssubstanzen. Viele, vermeintlich "feuersichere" oder "schwer entzündliche", neue Abdeckmaterialien brennen in mit Sauerstoff angereicherter Umgebung trotzdem und entgegen der Vorgaben als Brennstoffquelle. Als Hauptschwierigkeit stellt sich die Bewertung des tatsächlichen Umfangs der Bedrohung durch chirurgische Feuer und eines potenziellen Schadens dar. Es mangelt an dringend notwendigen Informationen; genauen Zahlen, einer systematischen Erfassung aller Feuer im Operationssaal und einer exakten Definition der auslösenden Variablen und Konditionen. Die Erweiterung etablierter Safe-surgery-Protokolle um die Komponente „Determinanten zur Entstehung chirurgischer Feuer" kann ein erster präventiver Schritt zu deren Verhinderung sein.

Schlüsselwörter

Feuer - Operation · Zündquelle · Sauerstoff . Vorbeugung 


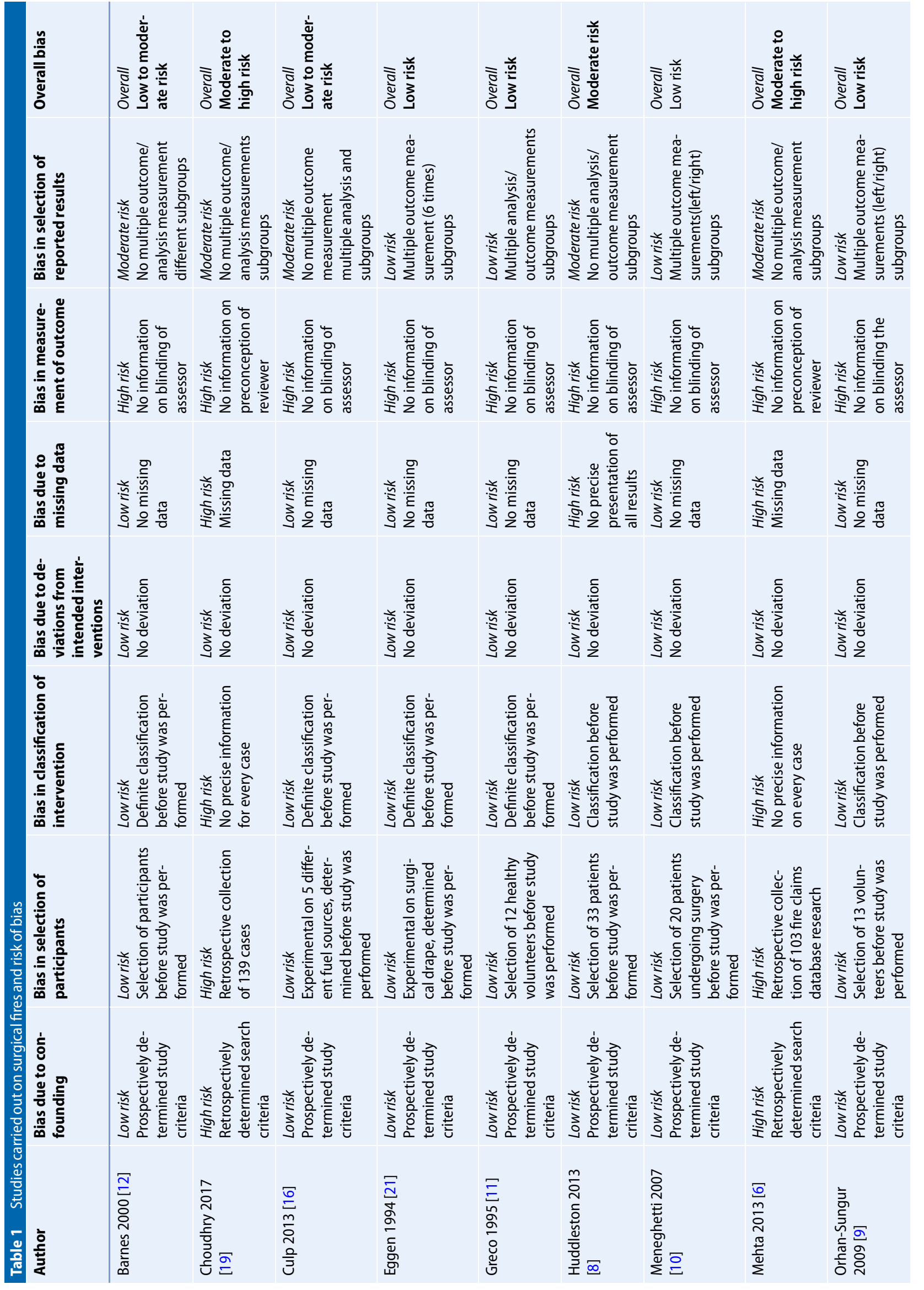




\begin{tabular}{|c|c|c|c|c|c|c|c|c|c|}
\hline 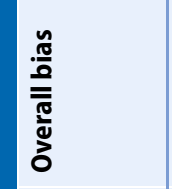 & 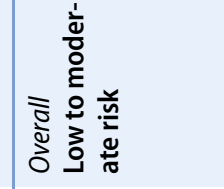 & 总 & 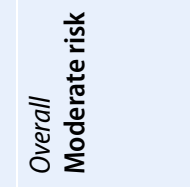 & 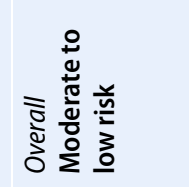 & 妾 & 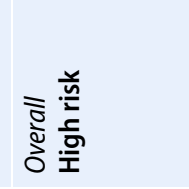 & 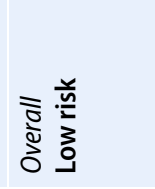 & 言 & 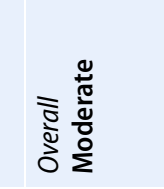 \\
\hline 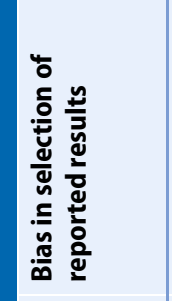 & 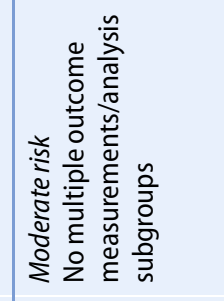 & 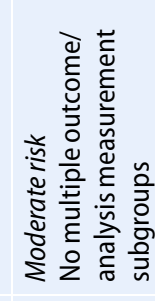 & 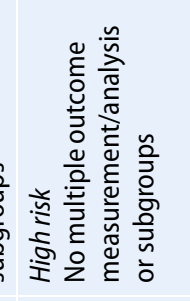 & 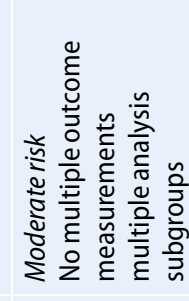 & 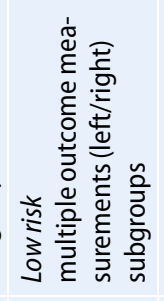 & 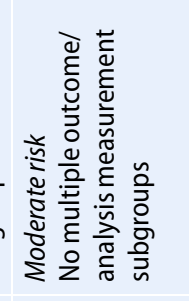 & 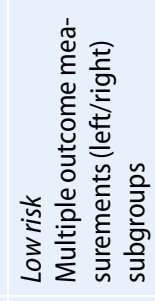 & 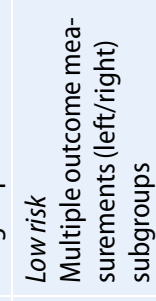 & 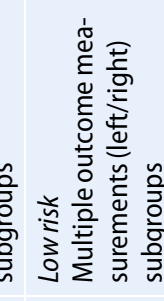 \\
\hline 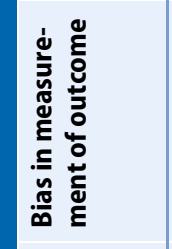 & 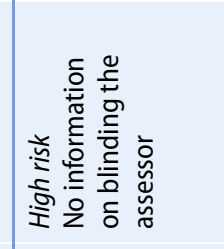 & 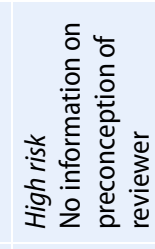 & 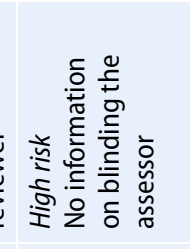 & 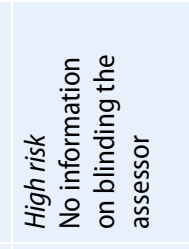 & 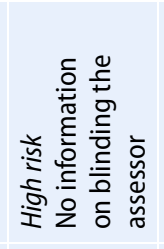 & 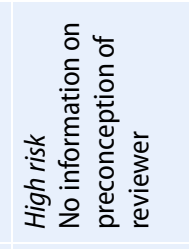 & 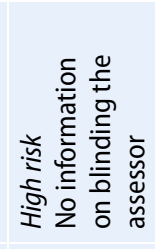 & 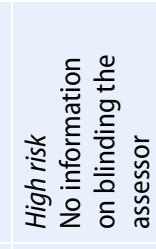 & 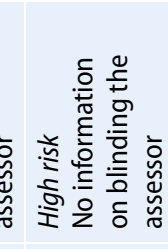 \\
\hline 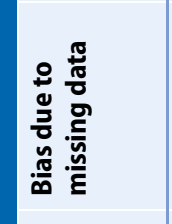 & 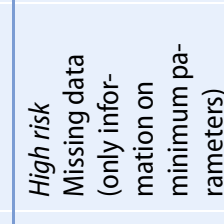 & 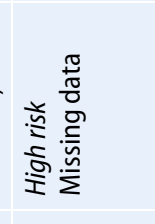 & 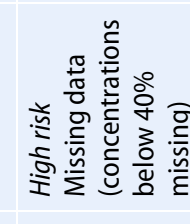 & 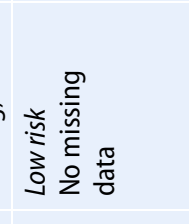 & 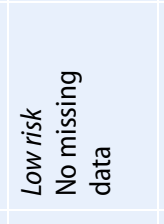 & 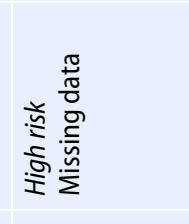 & 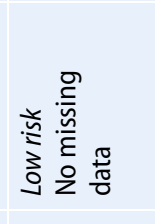 & 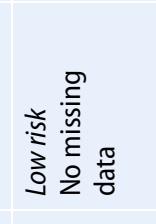 & 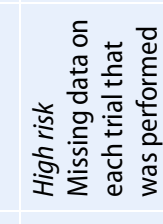 \\
\hline 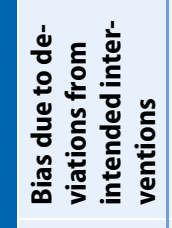 & 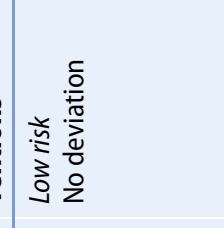 & 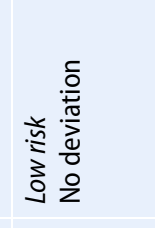 & 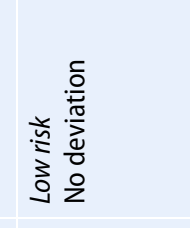 & 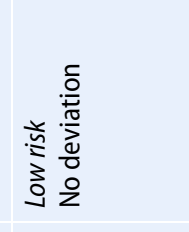 & 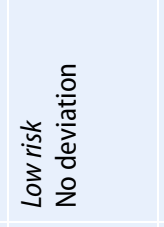 & 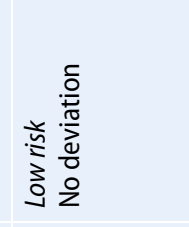 & 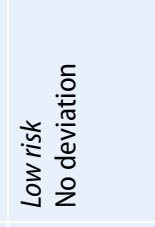 & 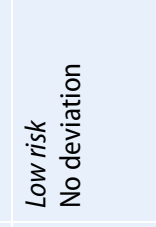 & 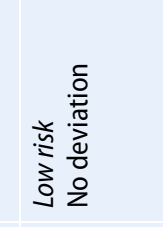 \\
\hline 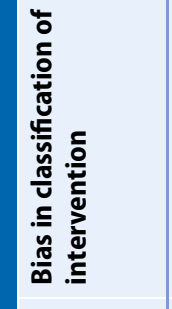 & 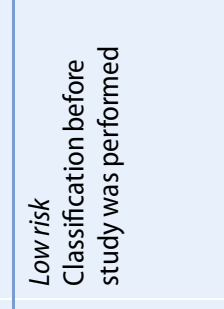 & 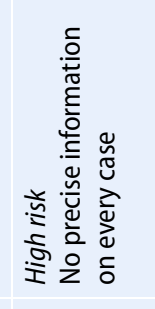 & 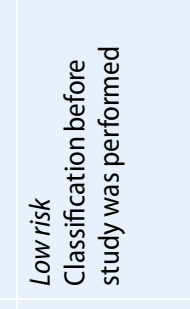 & 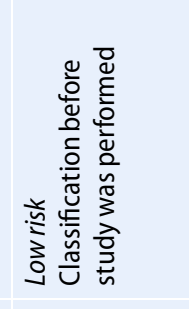 & 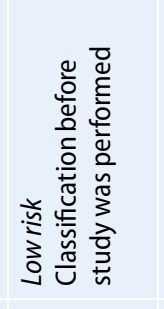 & 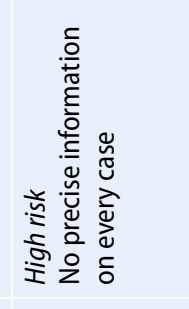 & 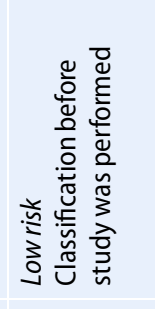 & 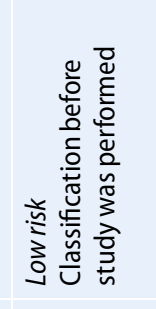 & 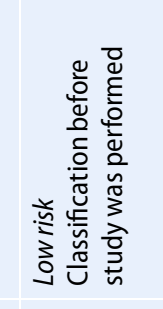 \\
\hline 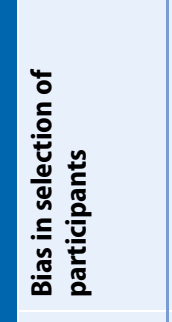 & 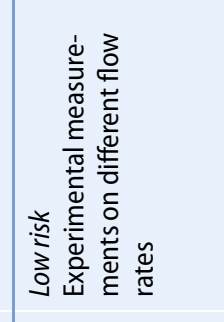 & 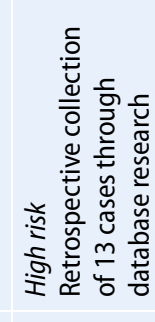 & 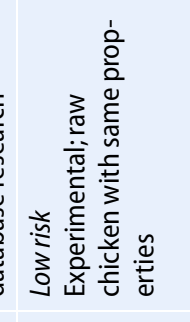 & 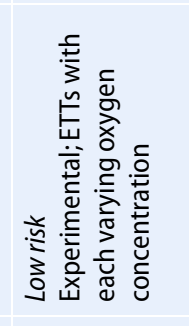 & 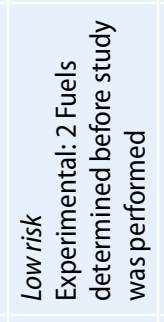 & 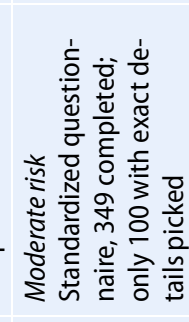 & 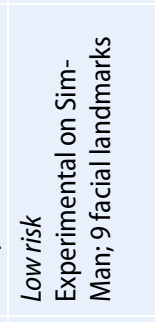 & 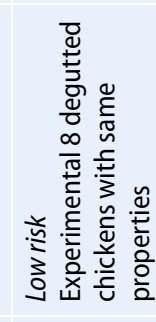 & 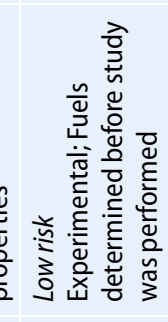 \\
\hline 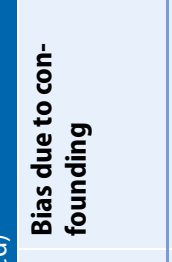 & 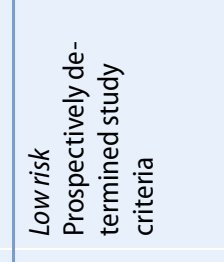 & 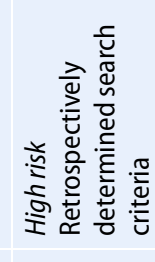 & 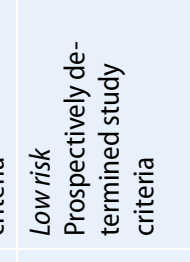 & 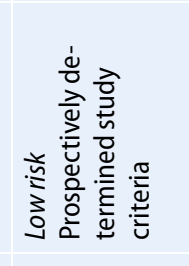 & 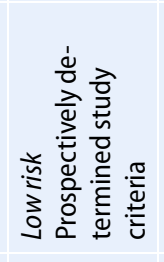 & 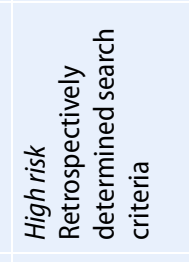 & 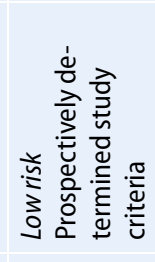 & 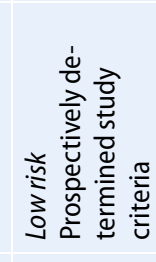 & 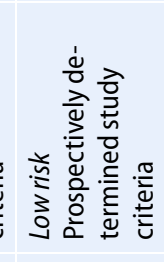 \\
\hline & 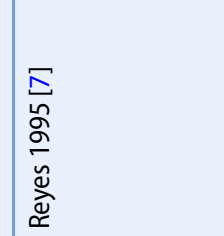 & 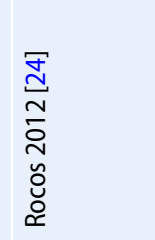 & 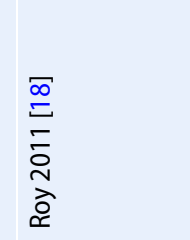 & 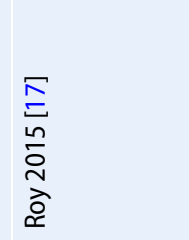 & 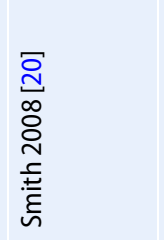 & 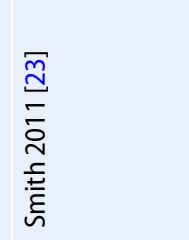 & 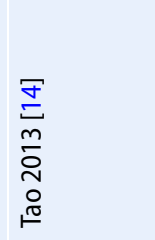 & 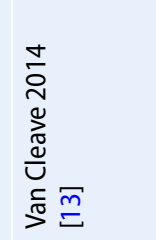 & 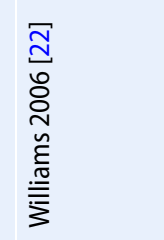 \\
\hline
\end{tabular}



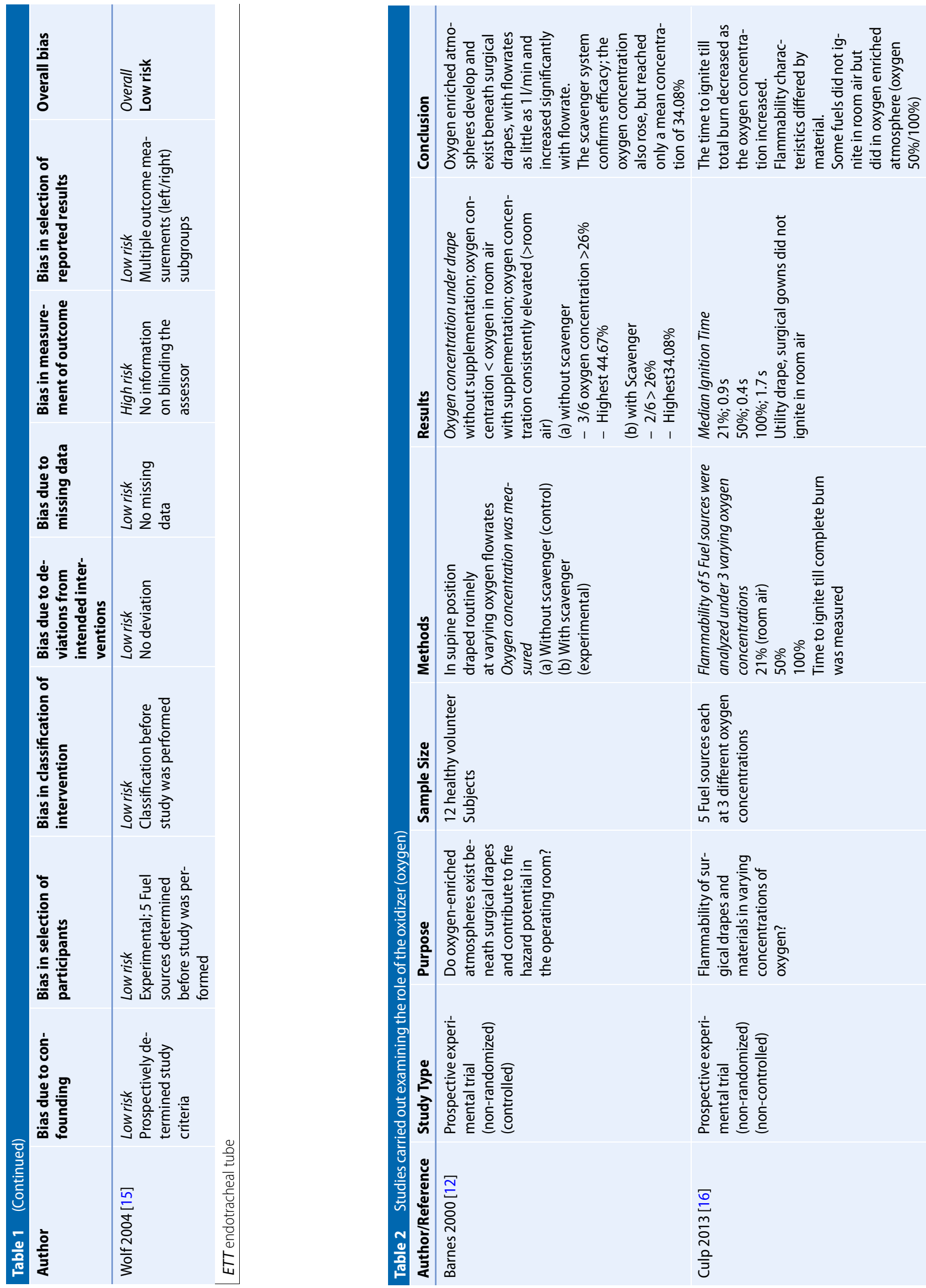

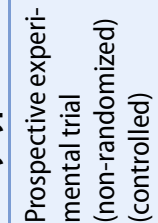

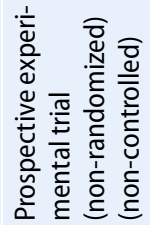

$\square$
$\stackrel{\Xi}{0}$
$\stackrel{2}{0}$
$\frac{0}{3}$ 


\section{Originalien}

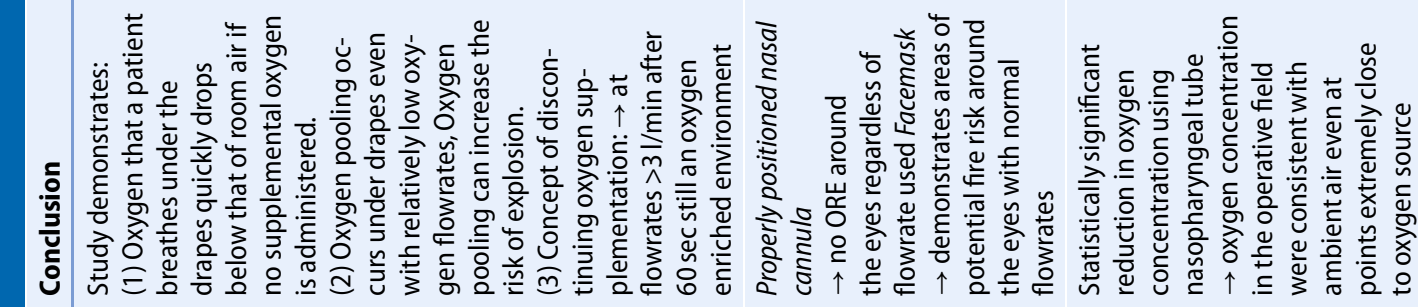
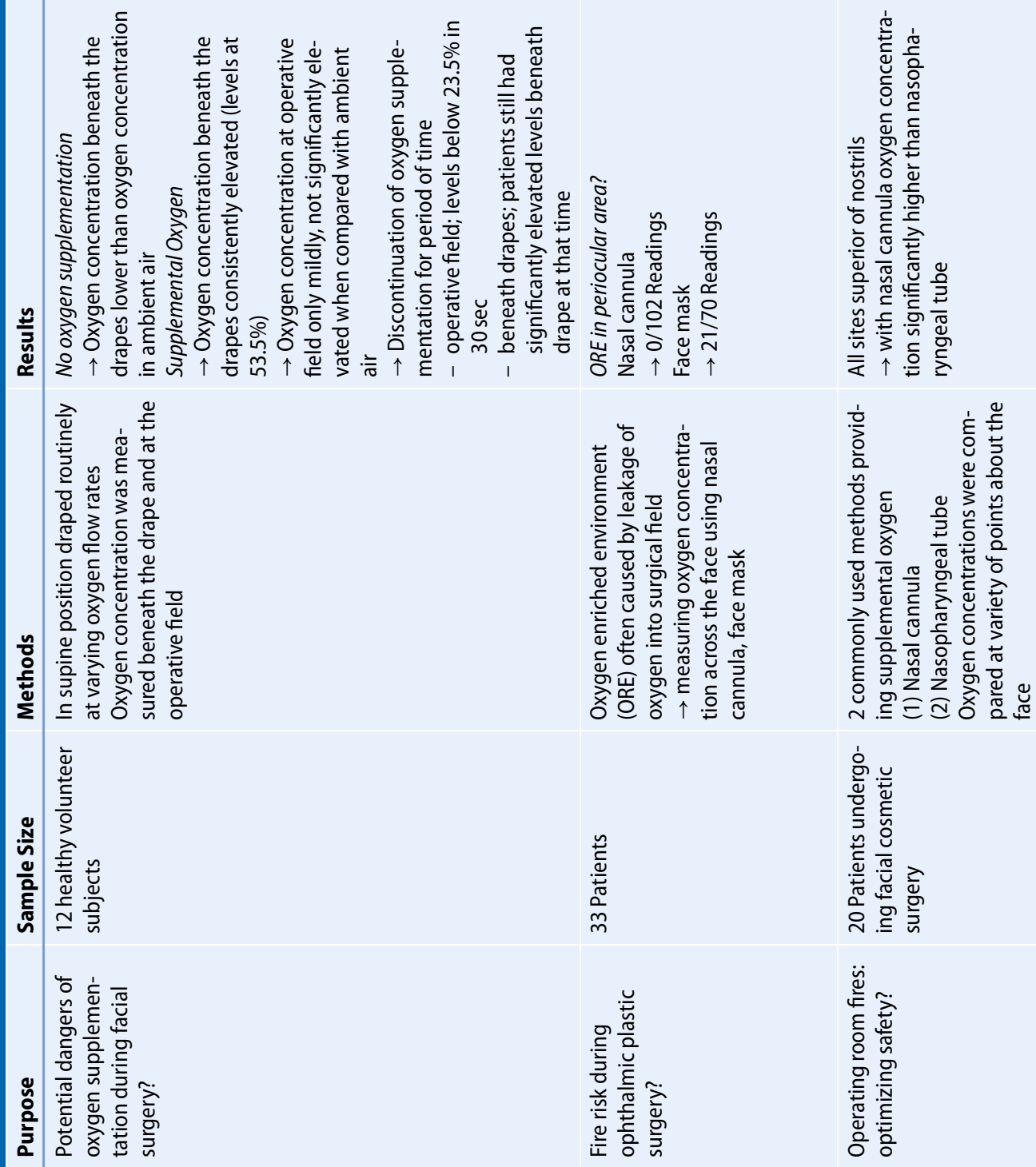

苞

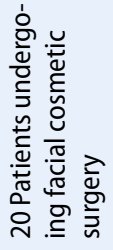

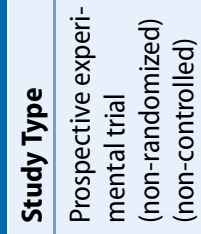
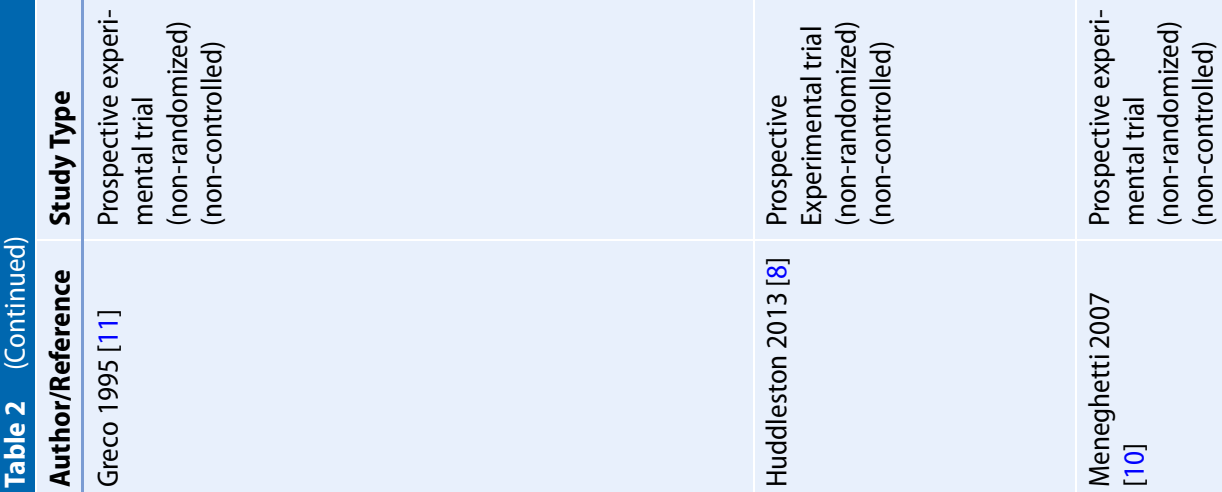

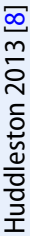

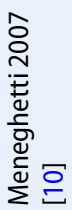




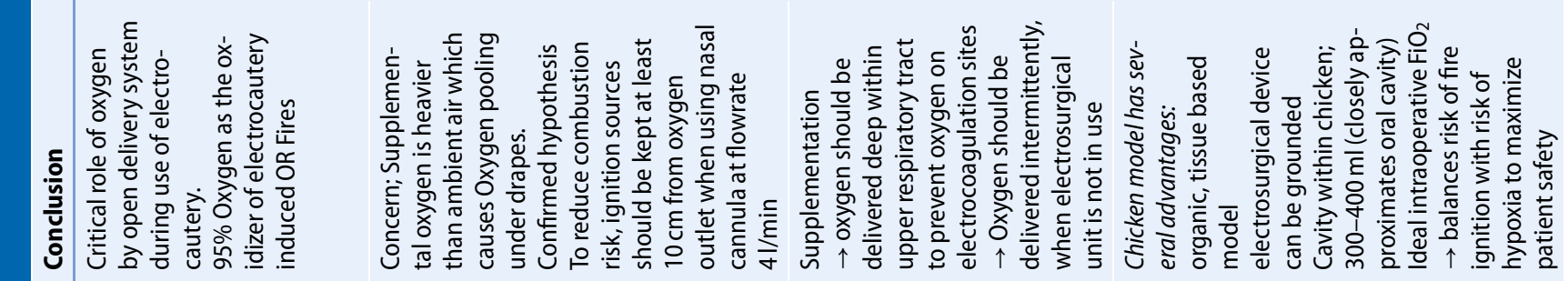
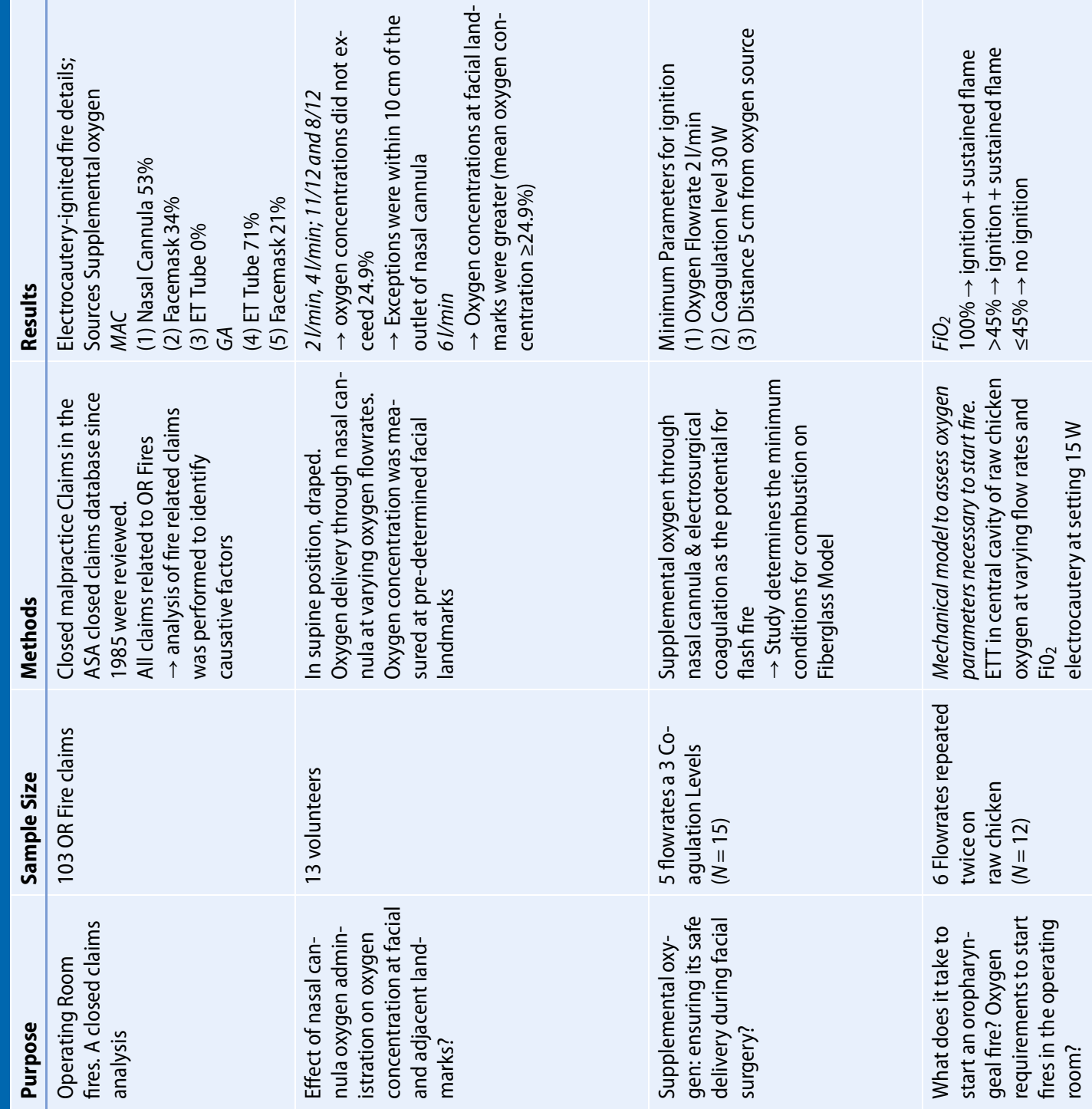

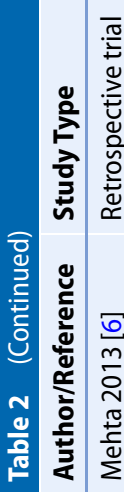
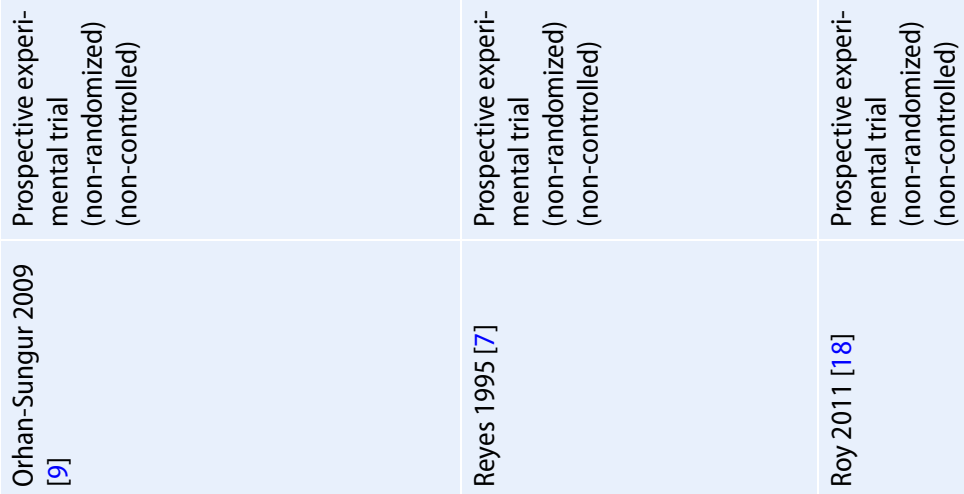

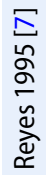

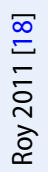




\section{Originalien}

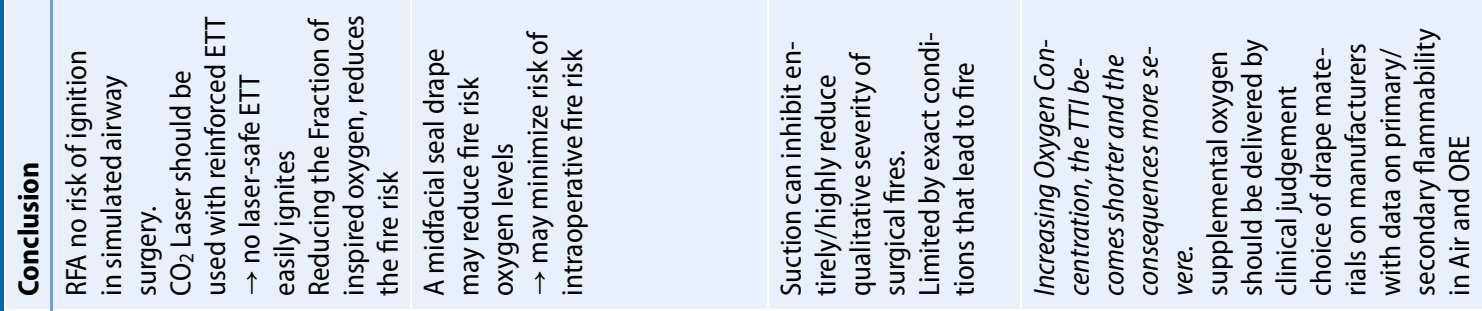
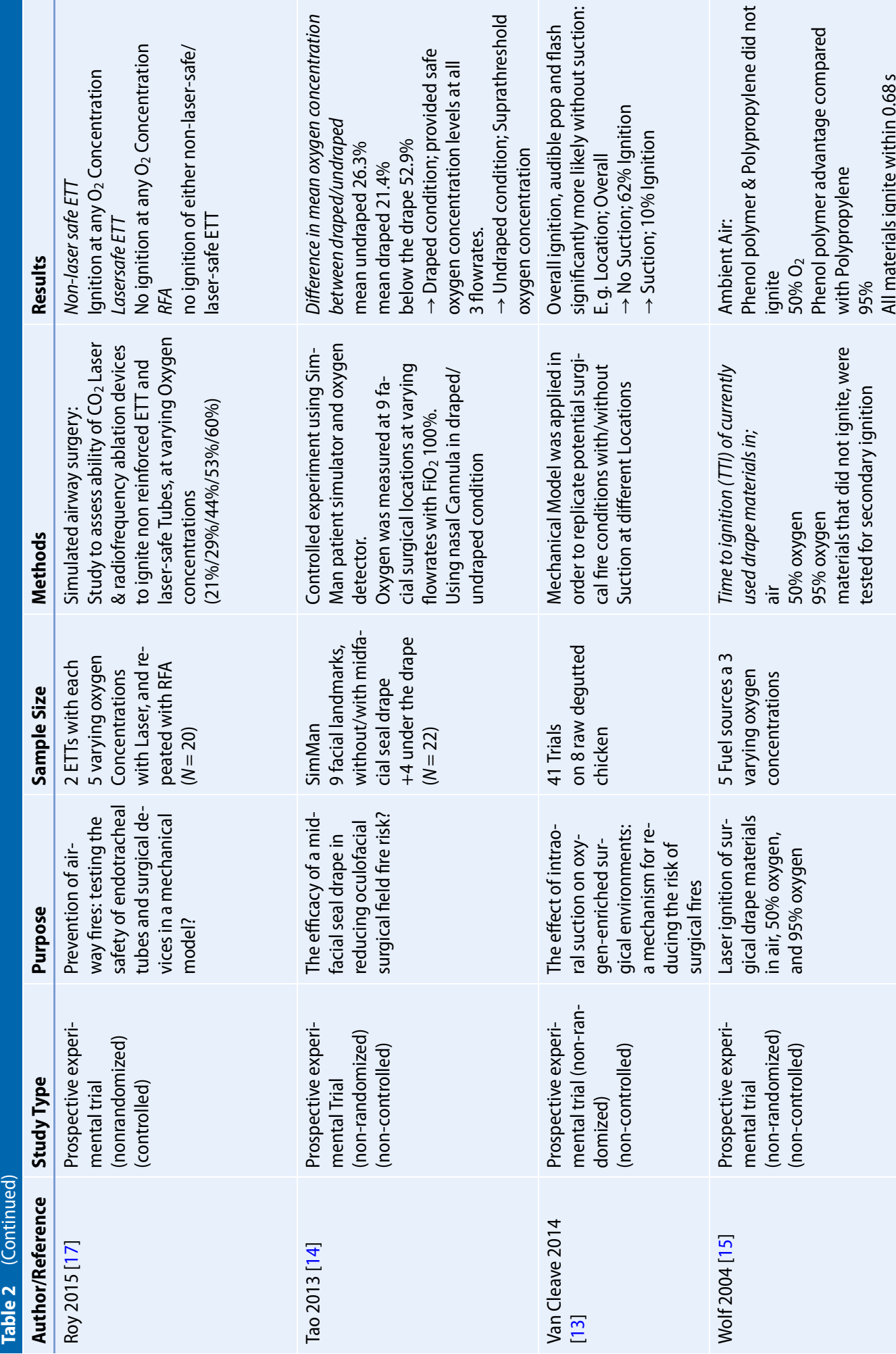

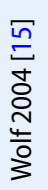

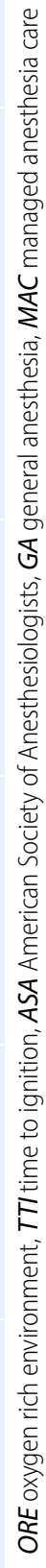




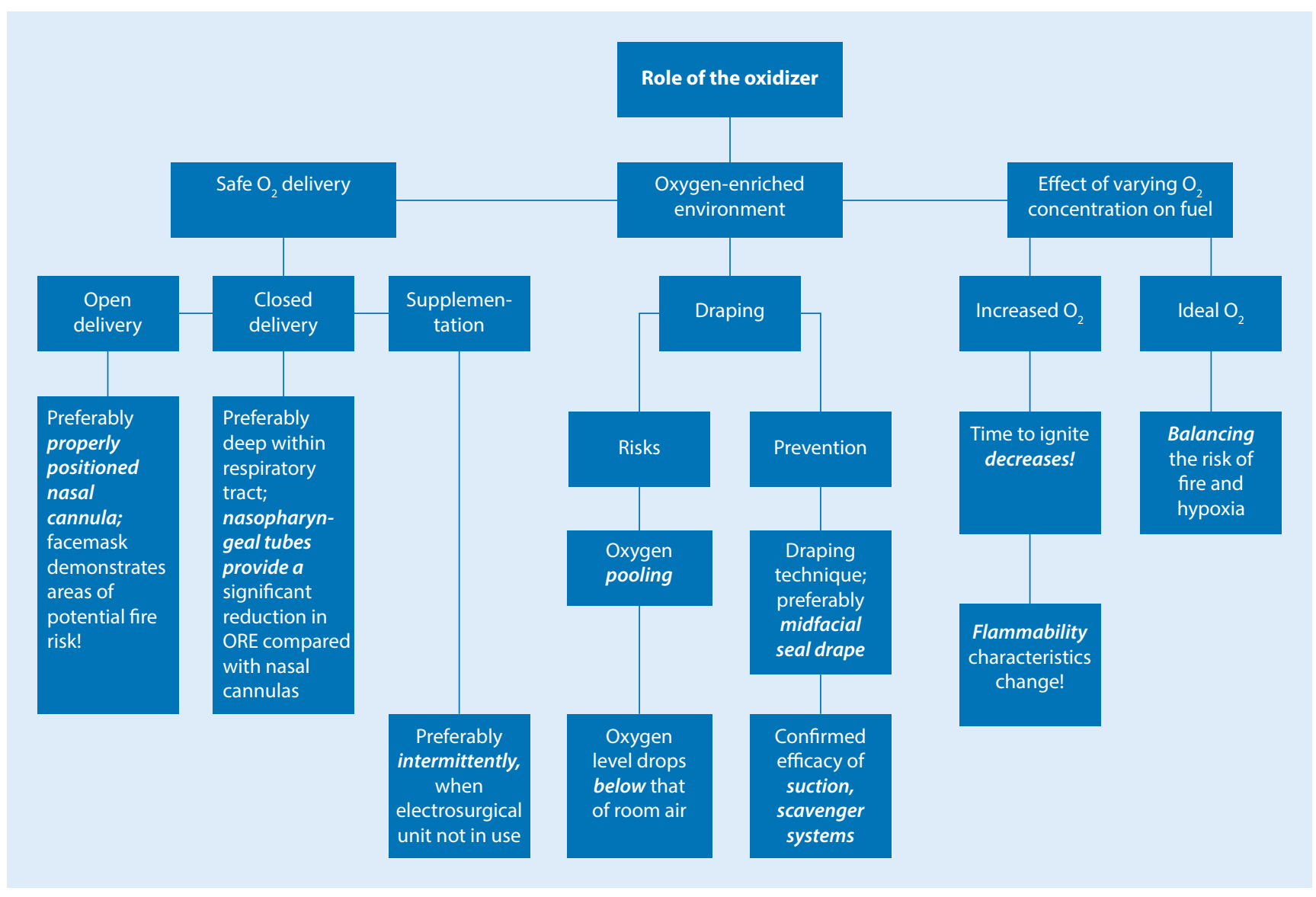

Fig. $2 \Delta$ Role of the oxidizer

fore cannot be summarized through a quantitative synthesis.

\section{Role of the oxidizer}

A total of 13 studies were included in the analysis regarding the role of the oxidizer (• Fig. 2): 12 studies were prospective experimental trials, and 1 trial was a retrospective analysis of closed claims related to surgical fires (- Table 2 ).

In summary, the identified studies assessed the oxygen concentration in different ways, following the premise and emphasizing that oxygen-enriched environments do contribute to a gross fire hazard risk. The evidence from these studies can be subdivided based on their main findings into 3 statements:

1. Safe oxygen delivery

- In $95 \%$ of cases, oxygen is the oxidizer in electrocautery-induced OR fires [6].

- Oxygen should be delivered deep within the upper respiratory tract and intermittently when an electrosurgical unit is not in use [7].

- Facemasks provide an ORE in comparison to a nasal cannula [8].

- For nasal cannulas, to reduce the combustion risk, ignition sources should be kept at least $10 \mathrm{~cm}$ from the oxygen outlet when using nasal cannulas at a $41 / \mathrm{min}$ flow rate [9].

- Nasopharyngeal tubes show a statistically significant reduction in oxygen concentrations in the operative field in comparison to a nasal cannula [10].

2. Oxygen-enriched environments due to draping are potentially reduced through scavenger systems.

- Without supplemental oxygen, the level of oxygen that a patient breathes under the drapes quickly drops below the level of oxygen in room air [11].

- Oxygen pools under the drapes $[11,12]$.
- Concept of discontinuing oxygen at flow rates $>31 / \mathrm{min}$ is not successful; oxygen concentration after 60 s still elevated [11].

- Suctioning/scavenger systems completely inhibit and/or reduce the qualitative severity of surgical fires [12, 13].

- A mid-facial seal drape may reduce the intraoperative ORE [14].

3. Effects of fuel characteristics on varying oxygen concentrations

- Time to ignite (TTI) shortens with increasing oxygen concentrations $[15,16]$.

- Flammability differs between material $[15,16]$.

- Reducing the fraction of inspired oxygen reduces the fire risk [17].

- A chicken model (organic tissue) shows that the ideal intraoperative $\mathrm{FiO}_{2}$ balances the risk of fire and risk of hypoxia $[15,18]$. 


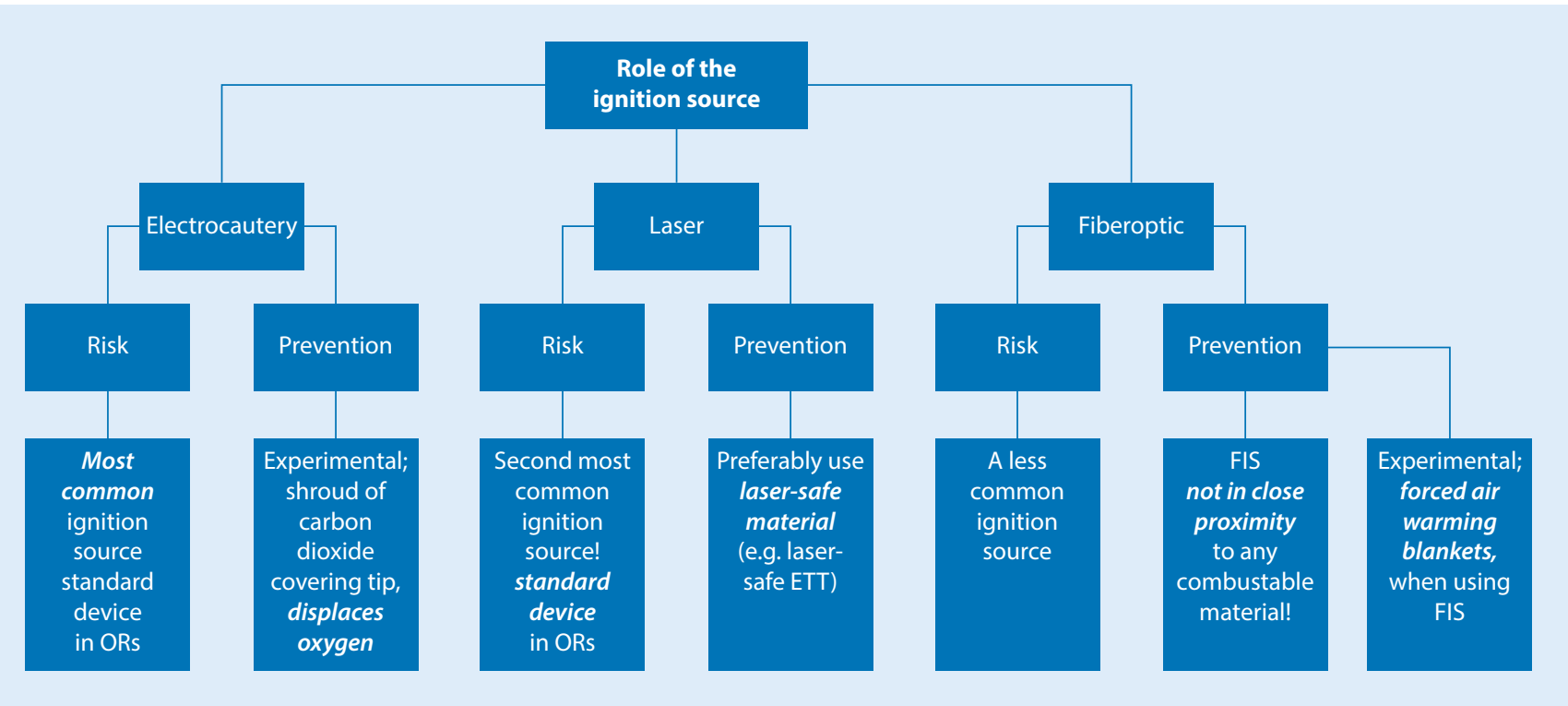

Fig. $3 \Delta$ The role of the ignition source - a synopsis of risk and prevention (ETT endotracheal tube, OR operating room, FIS fiberoptic illumination system)

\section{Role of the ignition source}

The included studies can be subdivided based on their main findings into 3 subgroups and statements (- Fig. 3, - Table 3).

1. Electrocautery

- High-energy devices (e.g., electrocautery) are the most frequent cause of ignition and injury [19].

- The electrosurgical unit is the most common ignition source (59\%) [20].

- Burn-/fire-related incidents with an electrosurgical unit are more frequent $(n=71)$ than those with fiberoptics $(n=25)$ [18].

- Of 103 fire claims, 90\% indicated electrocautery as the ignition source, $81 \%$ occurred during MAC (monitored anesthesia care), and 95\% occurred with supplemental oxygen [6].

- Supplemental oxygen should be used with caution and at a sufficient distance from electrosurgical devices [7].

2. Laser

- Non-electrocautery fires are mainly caused by medical lasers [6].

- Lasers are the second most common ignition source (32\%) [20].

- $\mathrm{CO}_{2}$ lasers should be used with only laser safe ETT and surgeons should consider alternatives such as RFA (radiofrequency ablation); laser-safe and regular ETT do not ignite [17].

3. Fiber optic

- Fiberoptic lights are one of the less common ignition sources [20].

- FIS is still a potential ignition source [21].

- With forced air warming blankets through fiberoptic light, no fires occurred, but on other materials, it still ignites [22].

\section{Role of the fuel}

In total, 5 studies are prospective experimental trials, with 3 trials being retrospective (• Fig. 4, - Table 4).

Overall, all studies assessed the most common fuels in different ways, following the premise that fuels labelled "fire resistant" still ignite in an oxygen-enriched environment.

Study matches can be subdivided into 3 subgroups based on their main findings.

1. Surgical drapes

- Drapes and towels are among the most common fuels [23].

- There are numerous cases of OR drape-related fires, with polypropylene drapes being less flammable than cellulose drapes [20].
- Of the tested drape materials under room air levels of oxygen, mainly polypropylene lacked the ability to ignite, and cotton material rapidly burned [16].

- The choice of draped materials should consider the proximate use of ignition sources. No combustion in room air was observed with the tested materials phenol polymer and polypropylene, but when testing second ignition, only phenol polymer lacked the ability to ignite [15].

2. Alcohol preparation solution

- Alcohol preparation solution use has been identified in a number of electrocautery-induced fires [6].

- Despite manufacturers' warnings, surgical fires continue to occur mainly because alcohol preparation solution is not given sufficient time to dry or because drapes and swabs are often soaked in this solution at an unsafe distance from a potential ignition source [24].

3. Fire-resistant versus regular fuels

- Being the most common fuel identified, reinforced laser-safe ETT that are tested are fire safe and do not ignite while using $\mathrm{CO}_{2}$ laser [23]. Only the distal tip (not reinforced) is not fire resistant [17]. 


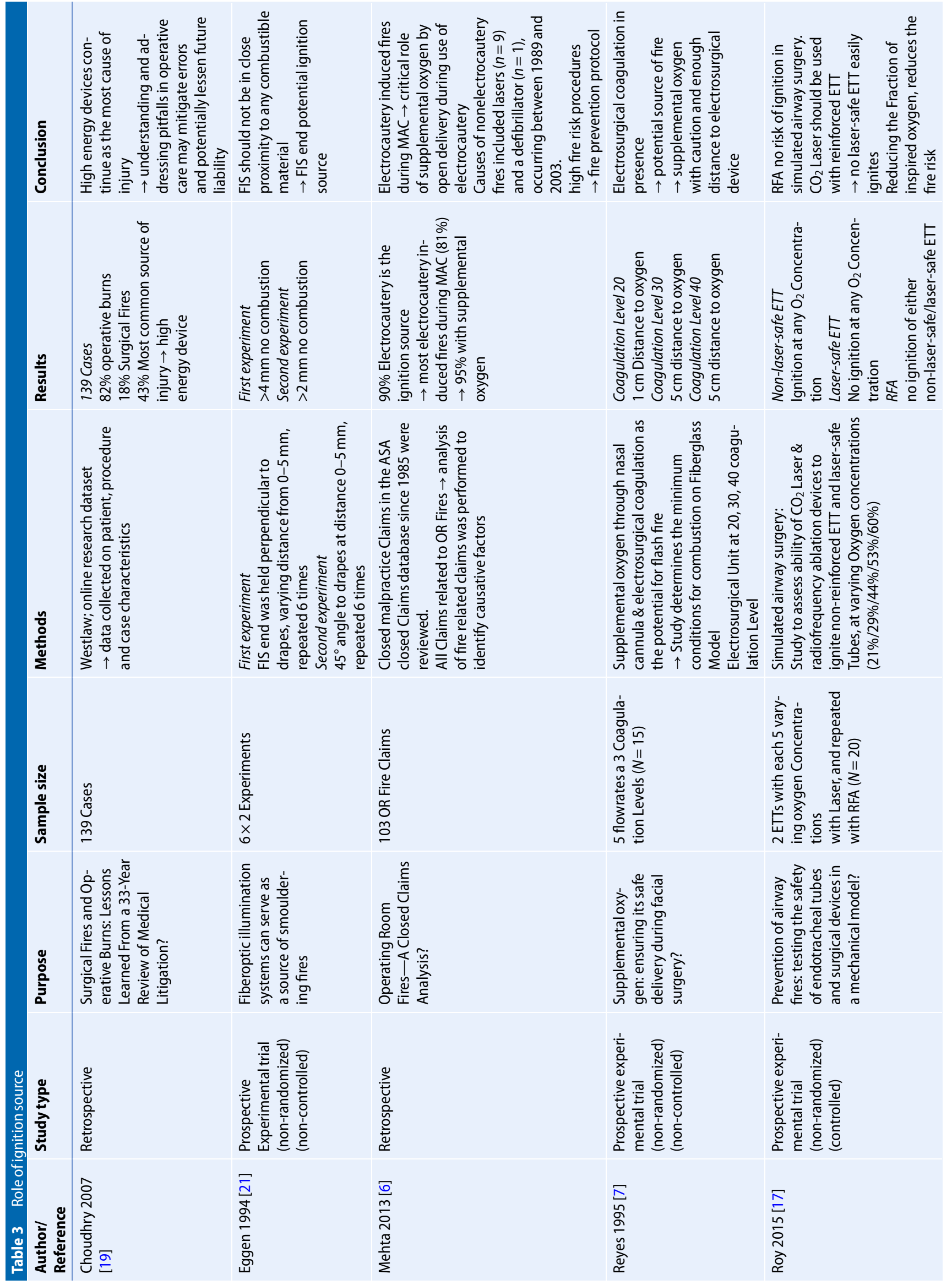




\section{Originalien}

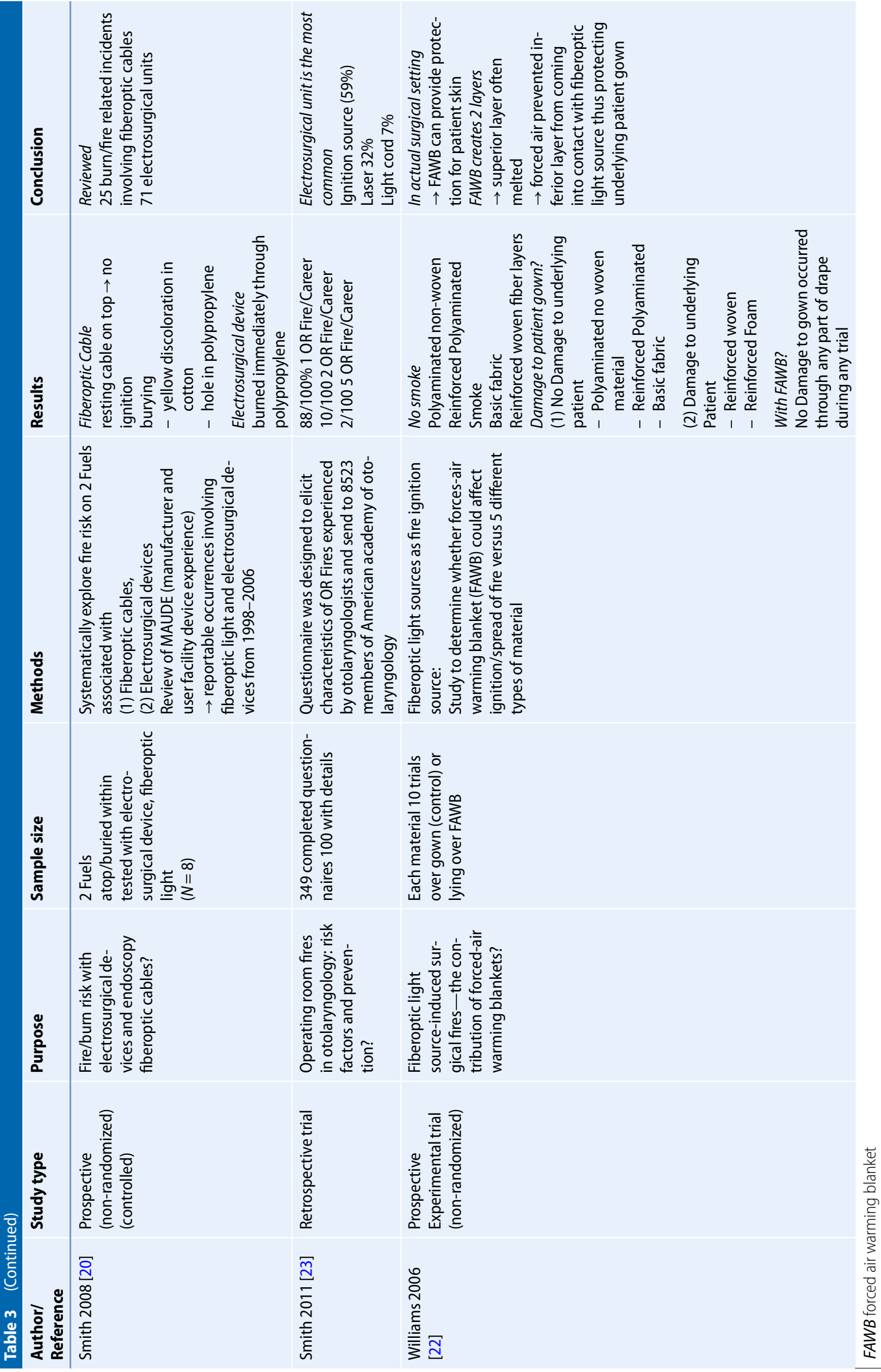




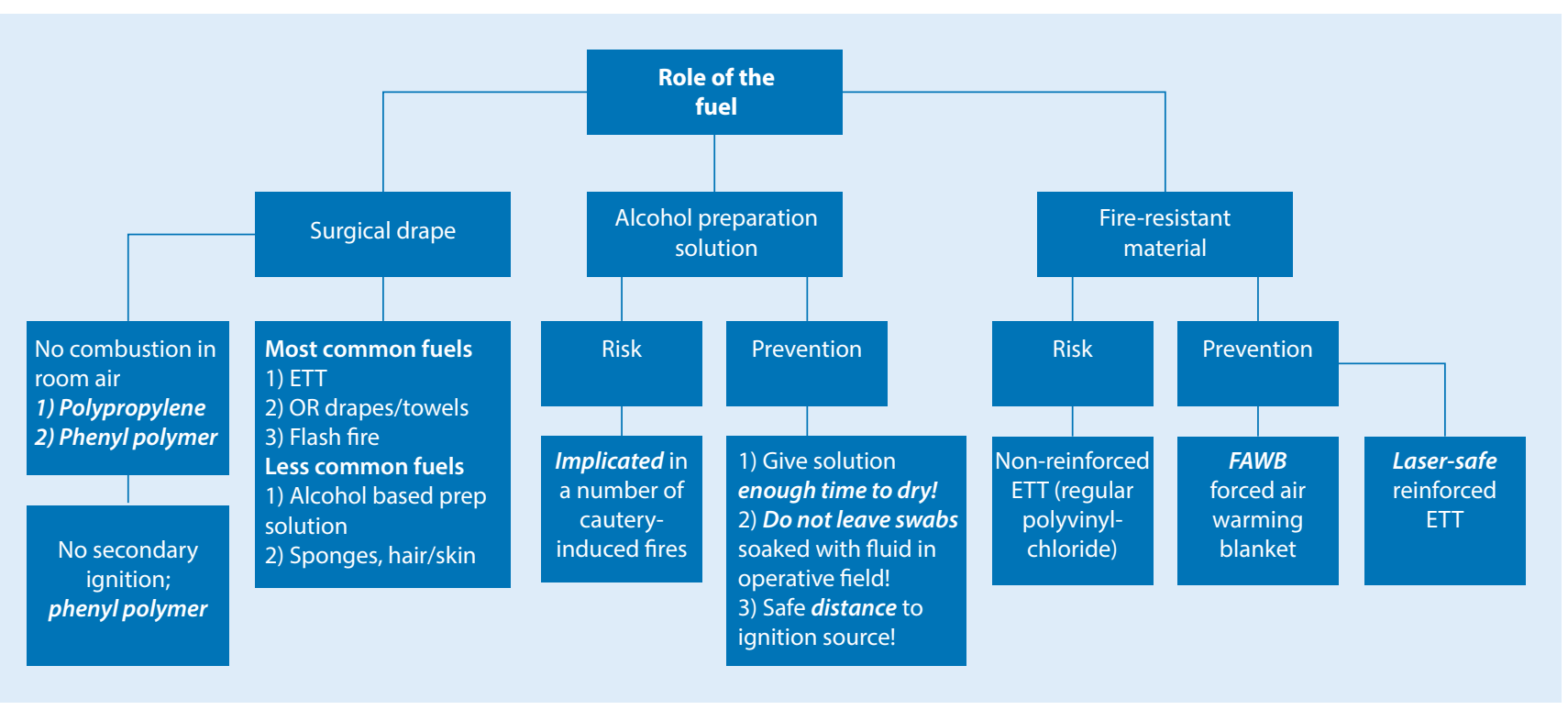

Fig. $4 \Delta$ Role of the fuel

- A forced-air warming blanket (FAWB) can provide protection to the patient's skin. The FAWB creates 2 layers. The superior layer often melts, whereas the forced air prevents the inferior layer from coming into contact with the ignition source [22]

\section{Discussion}

\section{Role of the oxidizer}

Oxygen is crucial for breathing. Despite being crucial for life, oxygen is an element with potentially devastating consequences. In the context of surgical fires and the fire triad, oxygen plays the key role. No oxidizer means no oxygen feeding the fire. Hardly any specific fuel and ignition sources are needed when the oxygen concentration reaches $100 \%$ and autoignition becomes possible even for inert fuels, such as particles in dust or patients' hair. Only friction is needed for heat as an ignition source.

In summary, the major issue to prevent surgical fires is to prevent the occurrence of an oxygen-enriched environment (ORE). Illuminating the role of oxygen in fire ignition, we must understand that there is a lower flammability limit and an upper flammability limit (LFL and UFL). Limiting fuel concentrations may support flame propagation. Fuel concentrations outside that range are inflammable. The limiting oxygen concentration is the minimum $\mathrm{O}_{2}$ concentration that will propagate flame [25]. Oxygen enrichment significantly increases the fire hazard of materials by widening the specific flammability limits, namely, decreasing the LFL and increasing the UFL while decreasing the minimum energy needed for ignition. Material ignites more easily and burns more rapidly [26]. Nevertheless, choosing a fire-resistant and probably safe material is hard to realize because even if these materials are fire resistant in room air, their flammability characteristics change within OREs.

How does oxygen enrichment occur precisely? Supplemental oxygen leads to pure oxygen accumulating in the more basal regions covered by the surgical drapes. Oxygen is of a higher specific weight compared to room air and results in "oxygen pooling" [7]. Therefore, why not operate without supplementary oxygen?

In a spontaneously breathing patient, oxygen is utilized, and oxygen concentrations under tight drapes quickly drop below that in room air [11]. If supplementation of oxygen is necessary, which strategies might be safe to prevent an ORE? Van Cleave et al.[12] and Barnes and Frantz [13] both proved the efficacy of suction systems to clear the ORE under the drapes in order to prevent surgi- cal fires. A second optional intervention is keeping oxygen preferably in a closed supplementation system through intubation directly deep in the patient's respiratory tract to keep oxygen from leaking into the lower areas. Huddleston et al. [8] and Meneghetti et al. [10] proved that a nasal cannula inhibits the occurrence of OREs better than a facemask but is inferior compared to endotracheal intubation $[8,10]$.

Especially when an electrosurgical unit is used, it is suggested that oxygen delivery should be stopped for at least $1 \mathrm{~min}$ [27]. Thus, with higher flow rates of oxygen even after a $60 \mathrm{~s}$ stop in supplementation, an ORE is still present [11], and it is doubtable whether surgeons are willing to interrupt an ongoing operation for some minutes before electrocoagulation.

With respect to the surgeons' and scrub nurses' responsibilities for compatible hardware and situational awareness, it still remains the anesthesiologists' duty to maintain the balance between sufficient oxygenation and avoidance of hypoxia by managing to keep the supplementation of oxygen as safe and low as possible to prevent any hypothetic occurrence of a surgical fire. This might be achieved by using plain air and low concentrations of oxygen on healthy patients. 


\section{Originalien}

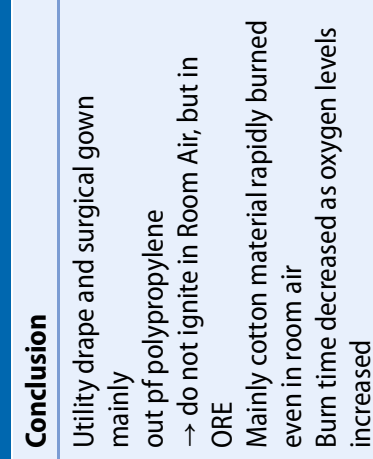

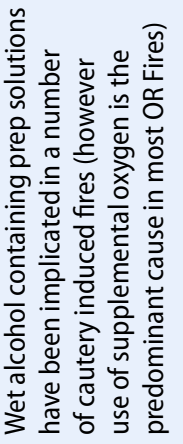

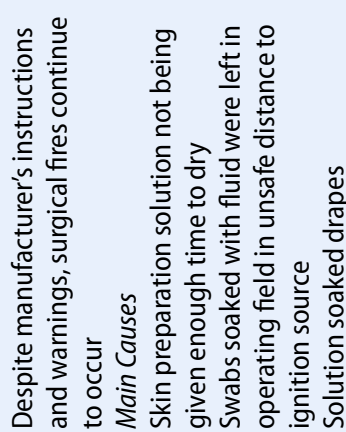

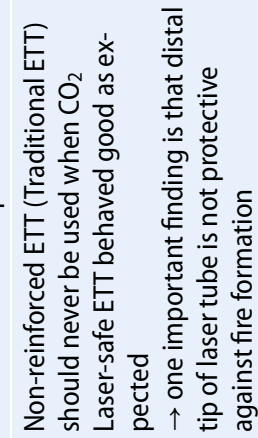

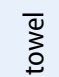

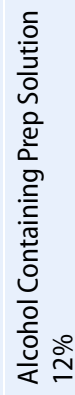
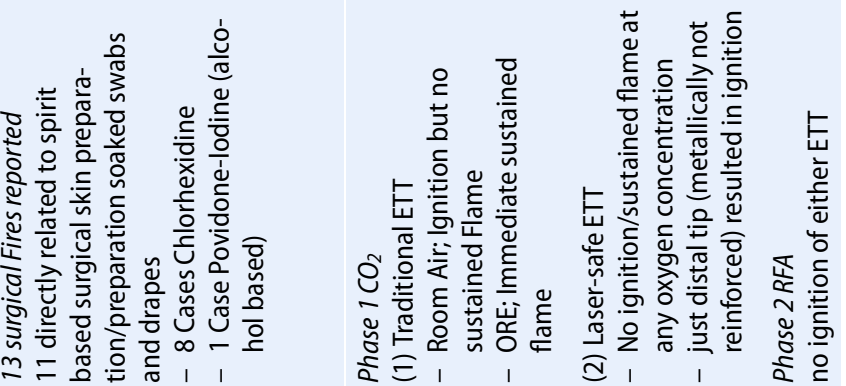

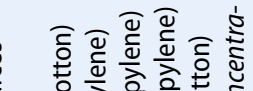

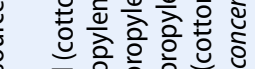

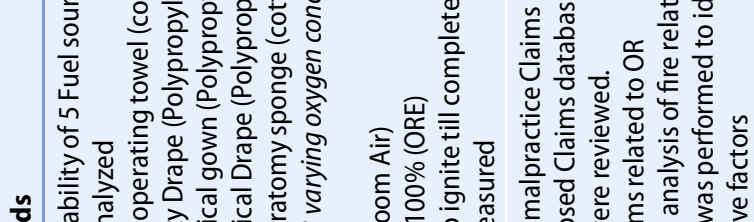

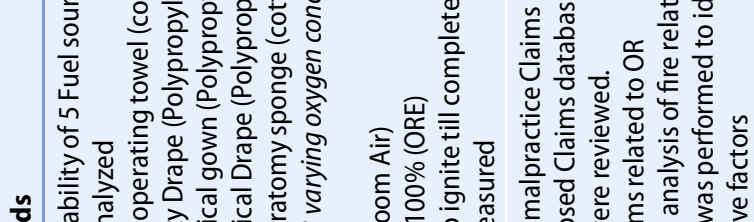

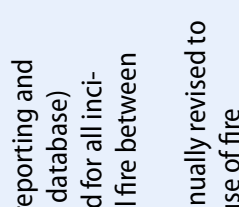

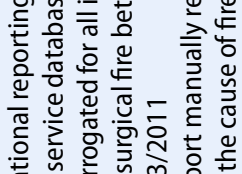

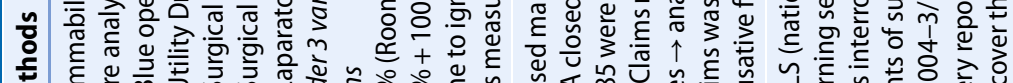

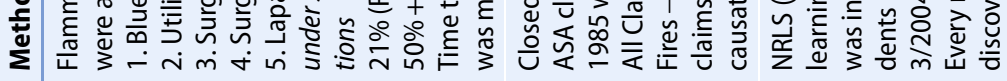

竞
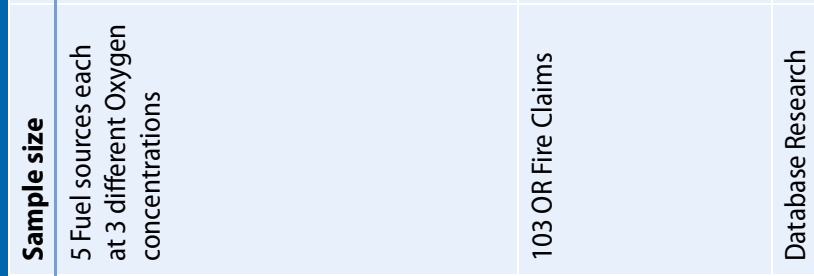

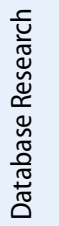
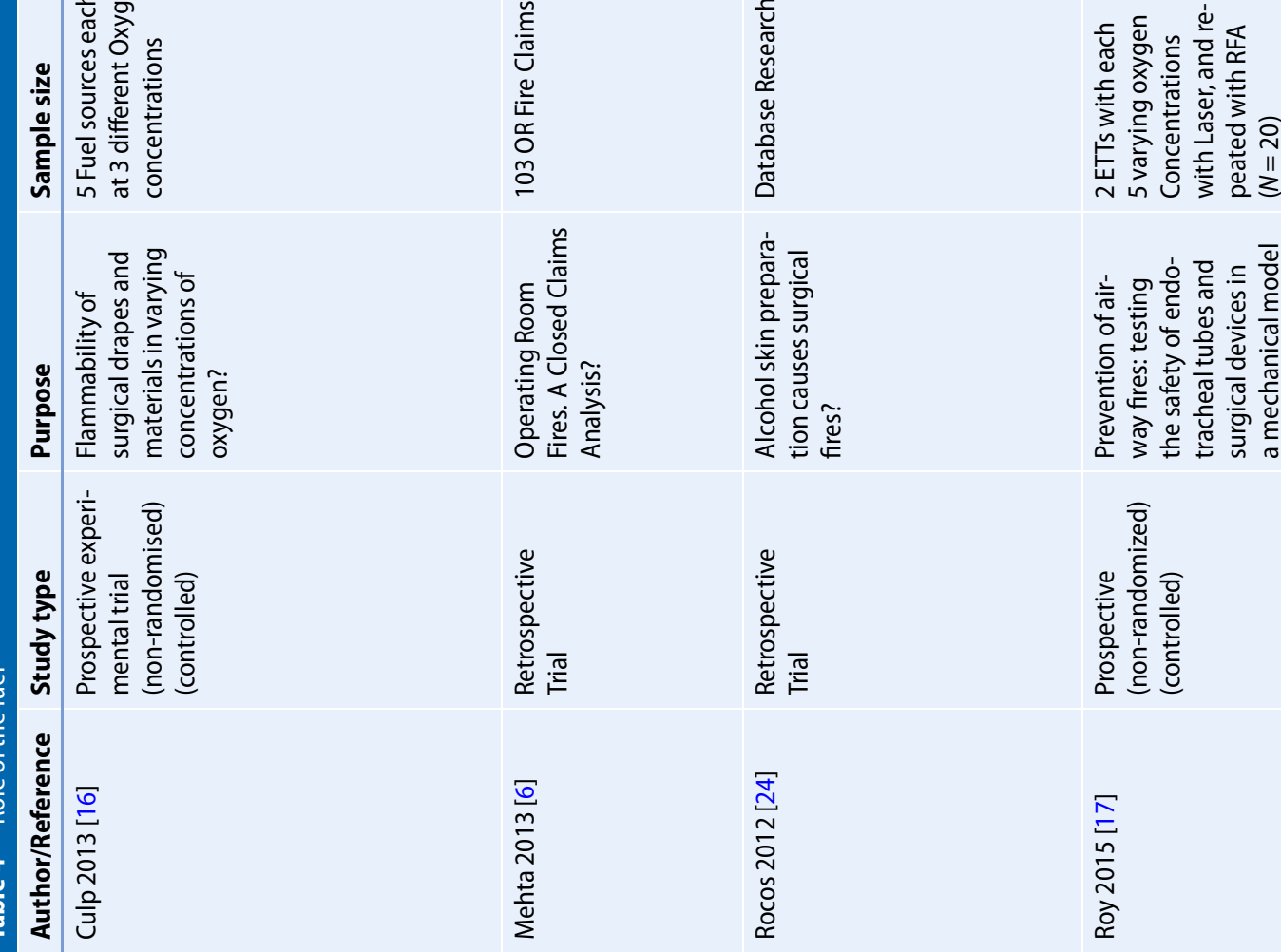

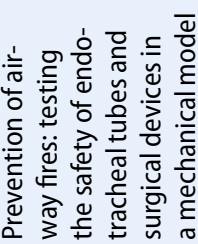

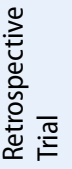

总

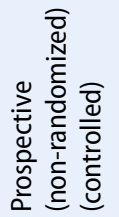

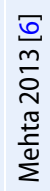

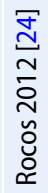

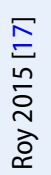




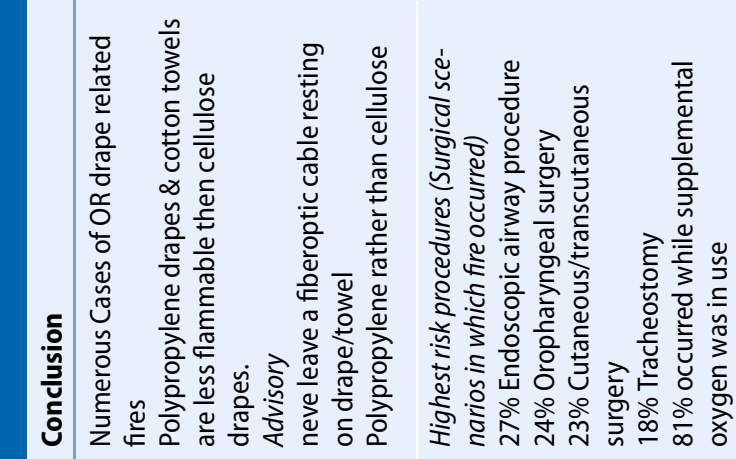
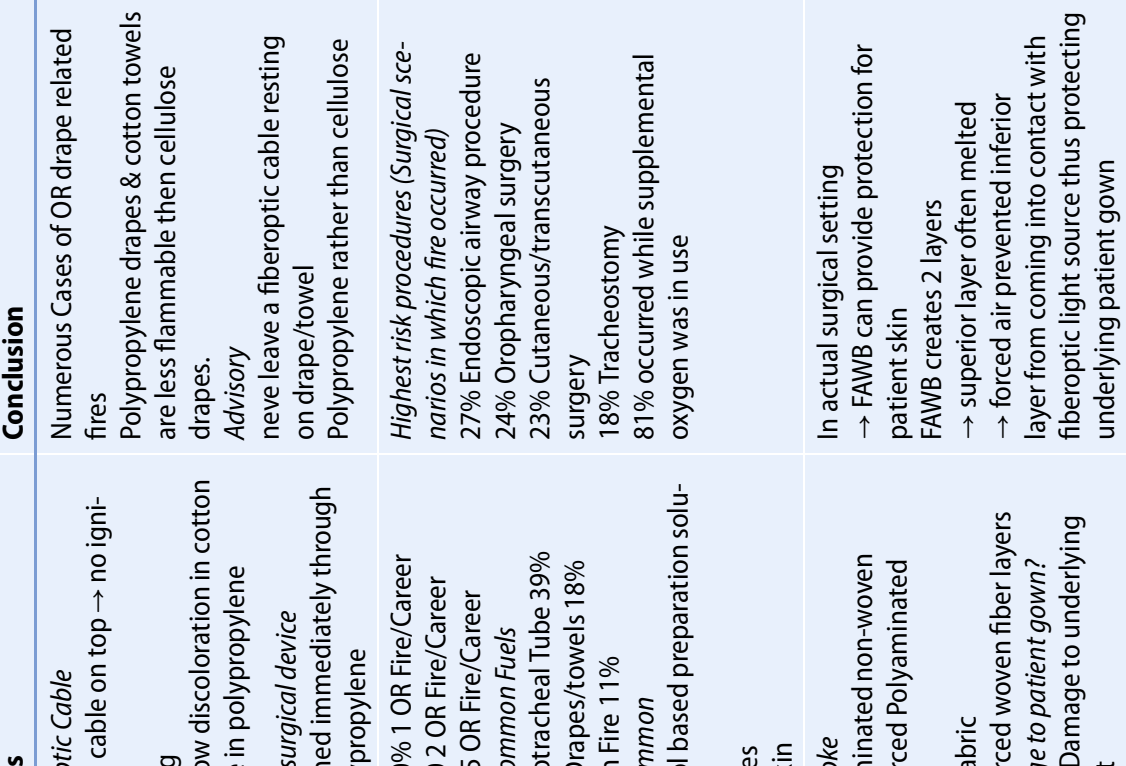

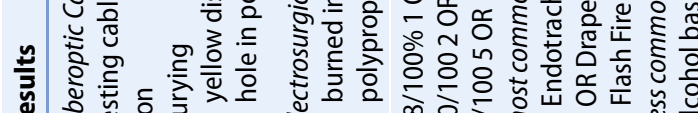
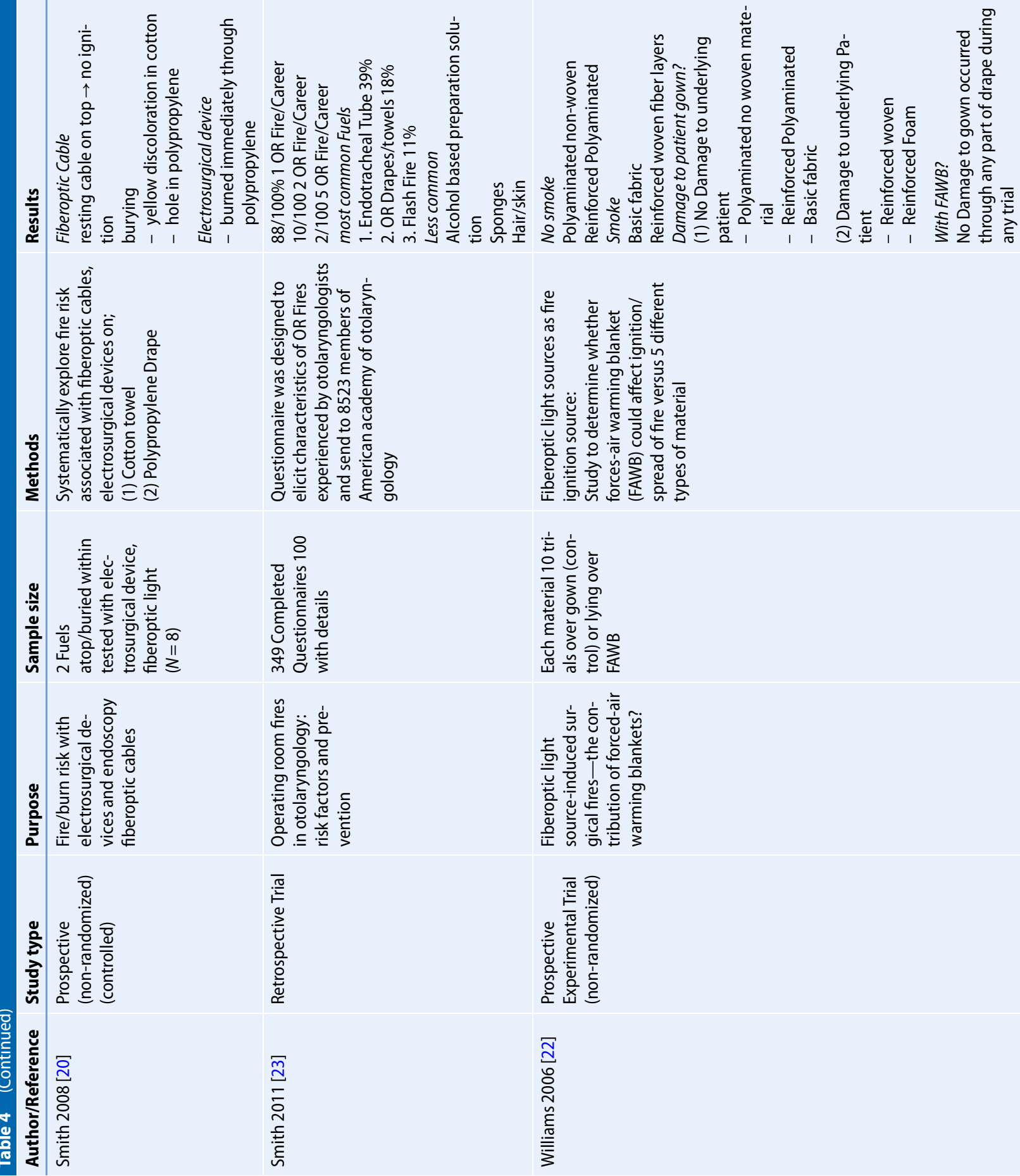

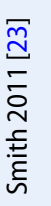

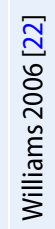




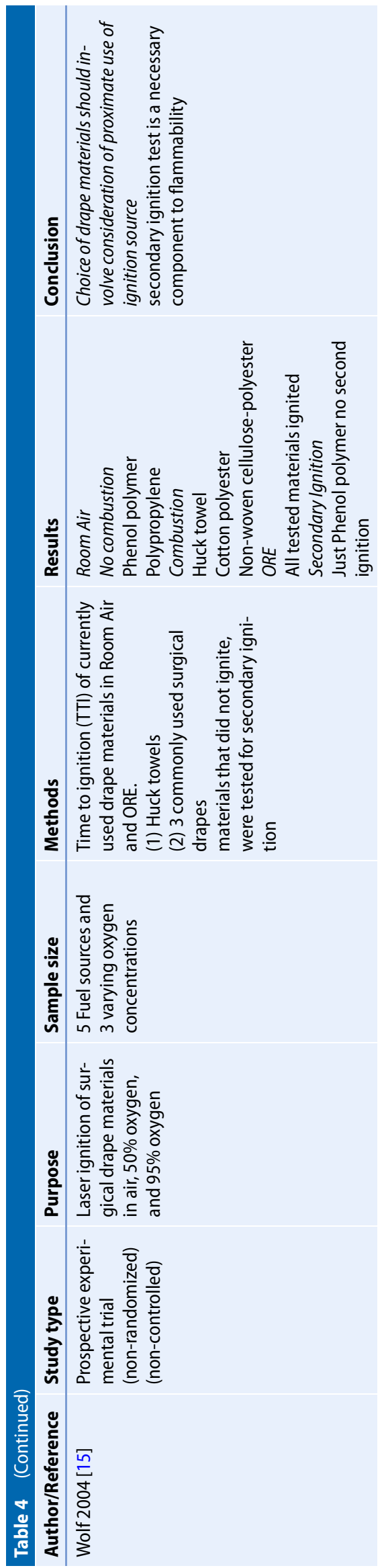

\begin{tabular}{ll}
$\begin{array}{l}\text { Table } 5 \\
\text { and gases }\end{array}$ & Flashpoints of various materials \\
\hline Paper & $360^{\circ}$ \\
\hline Cotton & $450^{\circ}$ \\
\hline Polypropylene & $390-410^{\circ} \mathrm{C}$ \\
\hline Phenol polymer & $480^{\circ}$ \\
\hline Polyvinylchloride & $455^{\circ} \mathrm{C}$ \\
\hline Isopropanol & $12^{\circ}$ \\
\hline Povidine iodine & $>100^{\circ} \mathrm{C}$ \\
\hline
\end{tabular}

\section{Role of the ignition source}

When reflecting on a fire in the operating room, the first thought might be how is it possible for a fire to ignite so easily in such a setting? In this context, we need to understand some basics of chemistry and physics. Chemically speaking, combustion is an exothermic redox reaction with heat emission. First, the educts are in a metastable state of equilibrium, e.g. carbon and oxygen react with activation energy to carbon dioxide and heat. Following this, the reaction continues independently due to the emitted heat serving as the activating energy. In accordance with the principles of Le Chatelier, if we raise the educt concentration parallel to the oxygen concentration, the equilibrium would move to the side of the products, causing more combustion [28]. For example, by raising the oxygen concentration, the activation energy needed is lowered [26]. At a certain point, the activation energy is so low that reactions are induced without any added activating energy. Energy is withdrawn by the surrounding area, resulting in exergonic, spontaneous combustion [28]. For activation energy in the context of a surgical fire, the ignition source is electrocautery in $90 \%$ of the reviewed cases [6], followed by laser energy [20]. In the case of laser application, the hazards of combustion are well known, and most of the time, necessary precautions are implemented. Using laser-safe endotracheal tubes instead of regular endotracheal tubes serves as a good example and might be neglected when electrosurgical units are used in this setting. When the activation energy decreases in an ORE, even a fiber optic cable might cause ignition [20,21]. High-frequency energy (syn. diathermy, electrosurgery, radiofrequency surgery) with at least $200 \mathrm{kHz}$ and up to $200^{\circ}$ is used to cut, devitalize, coagulate or thermofuse with low or no hemorrhage and belongs to the substantial surgical devices in every OR [29].

A laser is a technical device with a medium such as gas $\left(\mathrm{CO}_{2}\right.$ laser $)$ or a crystal (YAG laser) emitting radiation that has a particular wavelength. Laser light is absorbed by tissue and causes the thermal destruction of tissue proteins, meaning laser coagulation. The advantage of laser-associated surgery is the indepth precision it has. Additionally, it has several applications in ophthalmology, otorhinolaryngology and dermatology, which are high-risk disciplines in relation to surgical fires [30]. These high-energy devices are frequently used in highly specialized operations and might hardly be eliminated from clinical practice just to prevent surgical fires.

Frequent efforts have been made to make electrosurgical devices more fire safe in order to reduce the incidence of OR fires. A shroud of protective carbon dioxide covering the tip of the electrosurgical pencil displaces oxygen and hereby prevents ignition [31]. From the surgeons' point of view, knowledge of the risk on surgical fires during the procedure is mandatory, especially if an oxygen source is in near proximity to the surgical field. Second, it is crucial that there is a high level of awareness throughout the entire procedure. The high-energy device should never be left uncovered, and oxygen supplementation should be restricted or even stopped before the device is used.

\section{Role of the fuel}

In summary, frequent materials used in the operating room can serve as a fuel under the right circumstance. Smith and Roy [23] named the most common fuels: endotracheal tubes and surgical drapes. Less common fuels include preparation solutions and the patients' hair or skin. To define fire-safe materials, various surgical drape materials under varying oxygen concentrations have been investigated $[16,20]$. The materials tested showed that polypropylene and phenol polymer do not ignite under room air 
盛

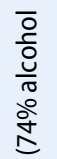

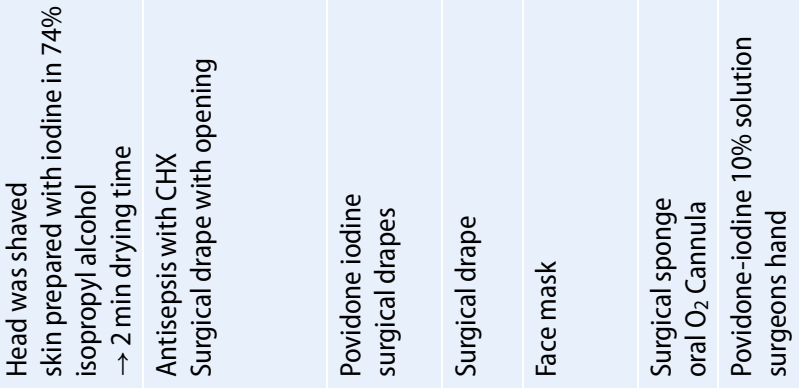

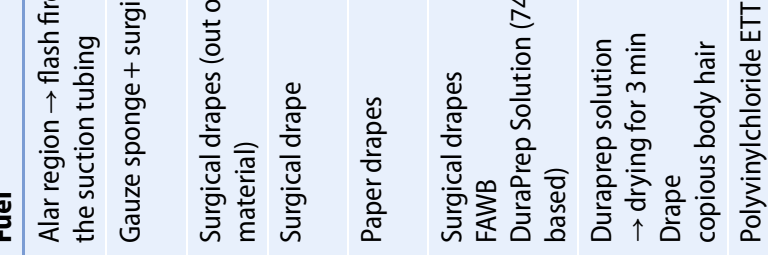

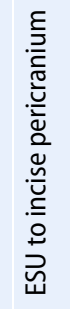

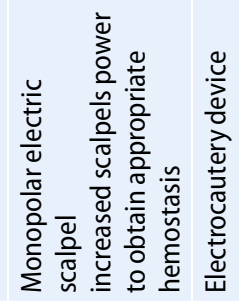

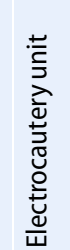

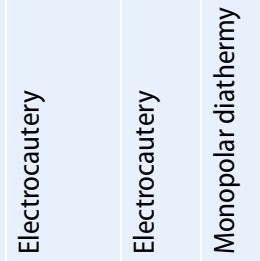

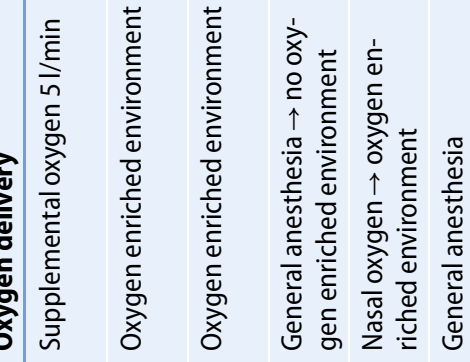

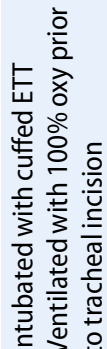

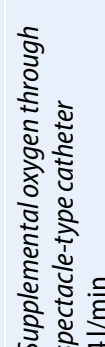

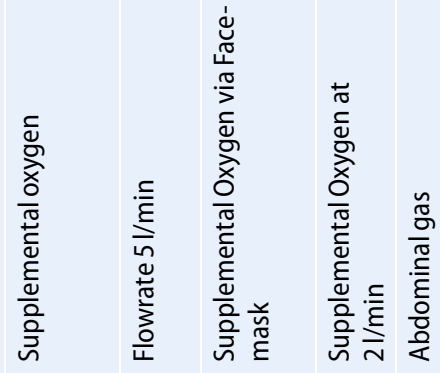

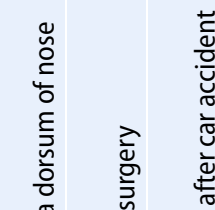

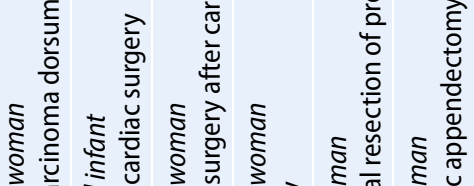

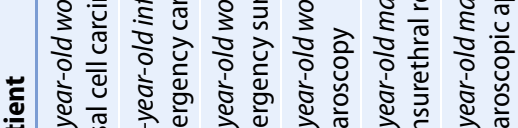

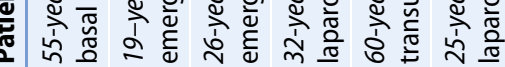

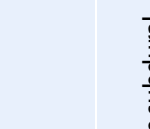

氶

苋

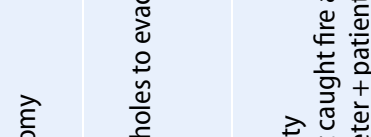

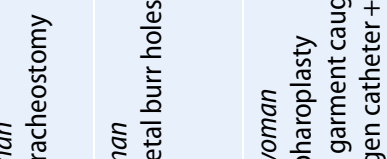

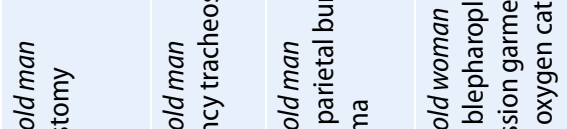

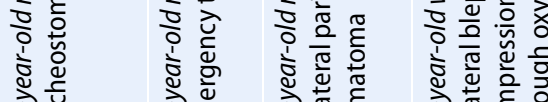

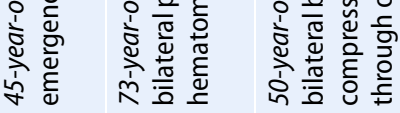

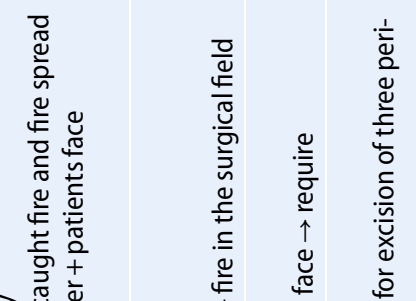

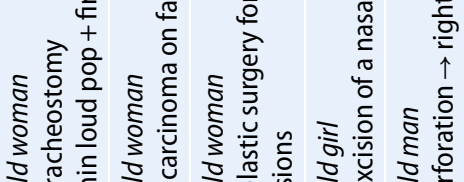

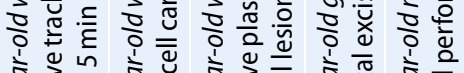

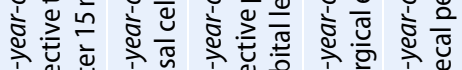

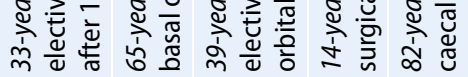
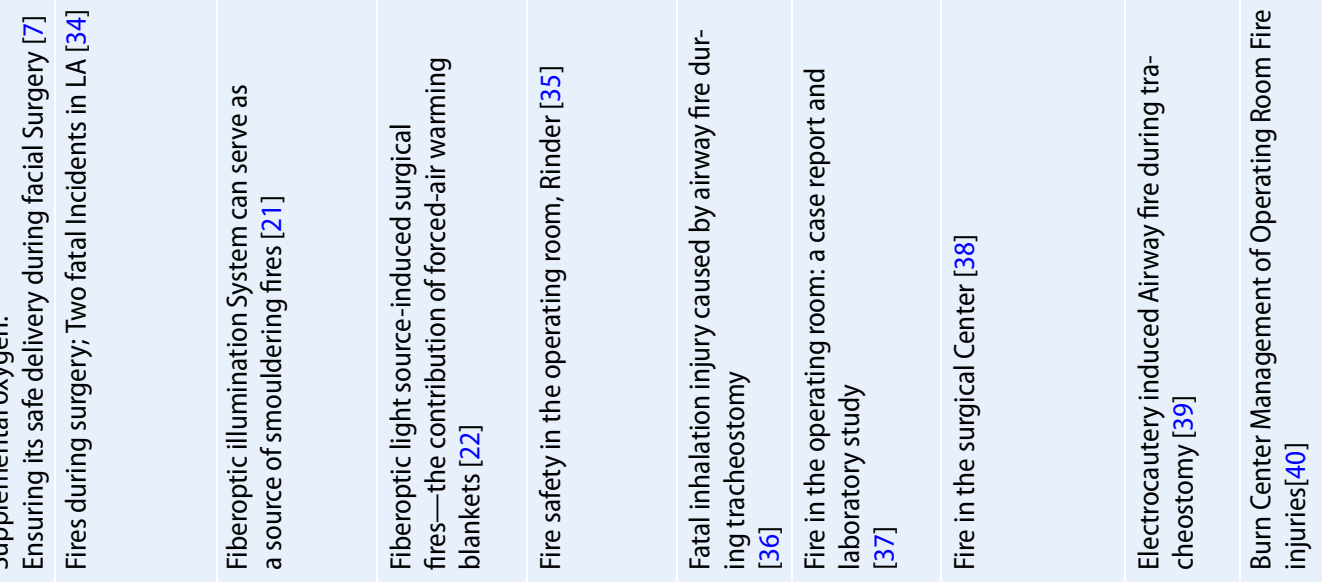


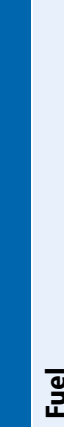
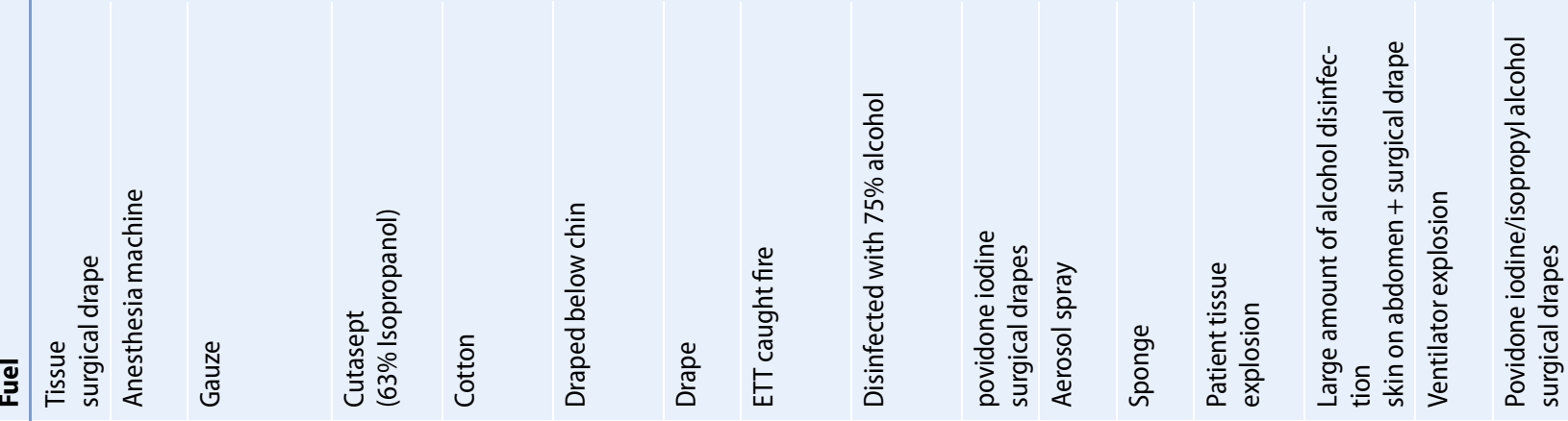

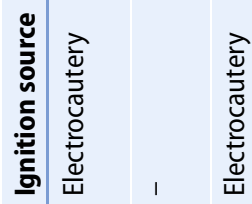

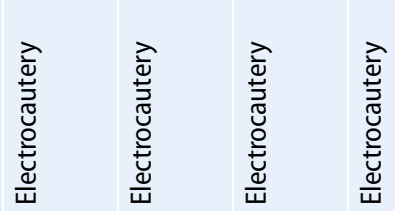

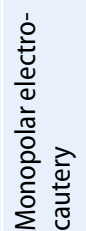
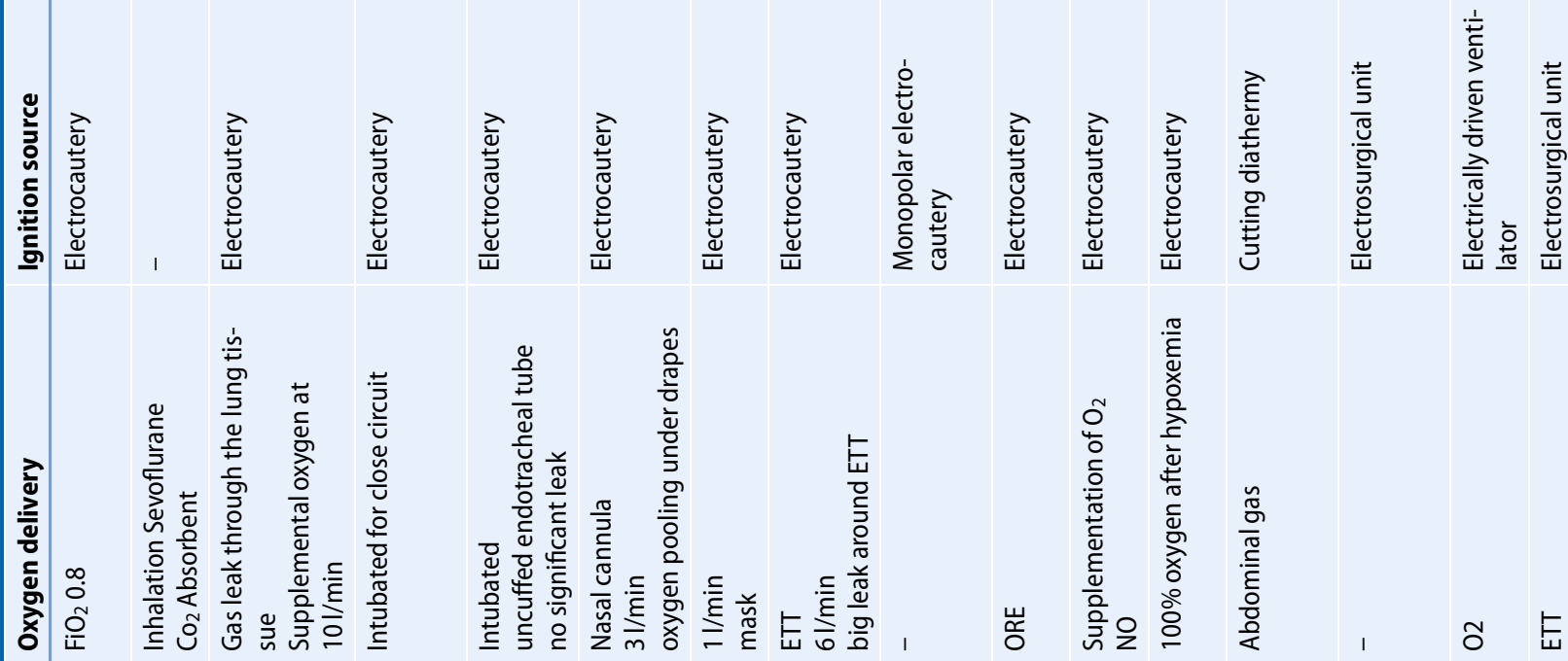

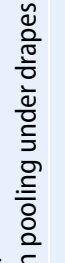

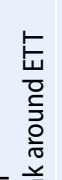
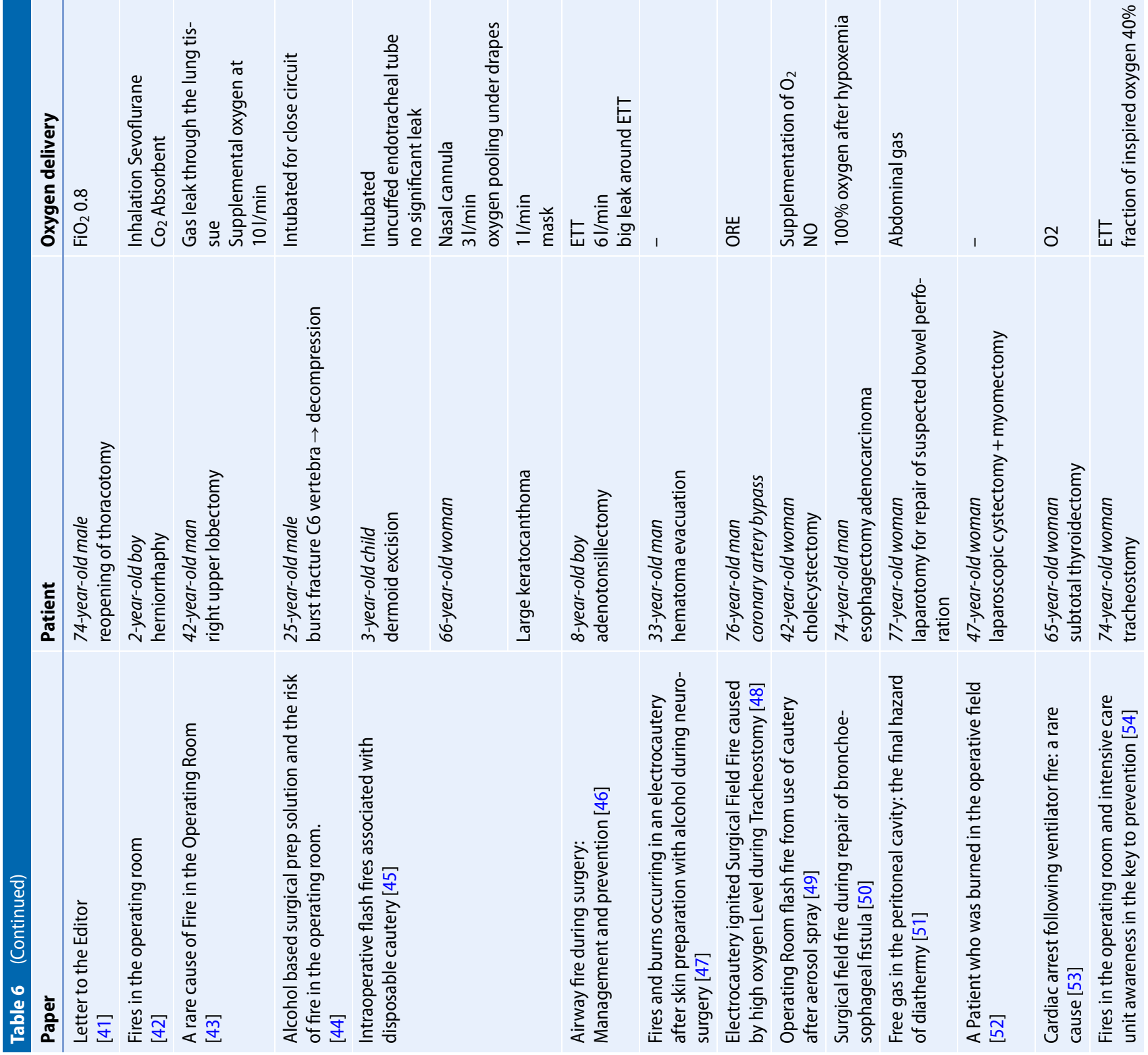
conditions. With respect to the flashpoints for gases/liquids and ignition temperatures for solids, all of them do have solid high temperatures ( $\bullet$ Table 5).

Of 35 case reports ( $\bullet$ Table 6 ), surgical drapes were frequently advocated as the fuel.

Ignition temperatures for solids (cotton, polypropylene or phenol polymer) are almost similar.

Cotton itself ignites very fast due to high permeability to air and has a higher surface than compressed synthetic material. Second, polypropylene or phenol polymer drapes are almost always strengthened with fire-resistant substances.

Preparation solutions are a less frequent but an unneglectable source of fuel. Povidone iodine itself has a flashpoint at $100^{\circ}$ but it is mostly a mixture containing $70 \%$ isopropanol [32], which has a flashpoint at only $12^{\circ}$ and is highly flammable. These solutions should always be given the right amount of time to dry and vaporize [27]. In analogy, for swabs, which are mostly made of cotton, the ignition temperature would be over $400^{\circ}$ but if they are still soaked in isopropanol and positioned around the operative field, they are a considerable hazard that may result in ignition and induction of a surgical fire.

For the prevention of surgical fires, the routine use of fire-resistant materials, dressings and blankets might be a hypothetical solution. Thus, most of these materials, even "inflammable" materials, might ignite in an ORE. For example, polypropylene and phenol polymer do not ignite in room air, but they do ignite in 50\% oxygen [16]. In addition, this concentration might be found under surgical drapes caused by "oxygen pooling". Thus, the component that seems to be the less influenceable is the fuel. Scrub nurses or operation assistants have to guarantee that highly inflammable materials, such as soaked drapes or swabs, are not positioned in proximity to any ignition source. Furthermore, preparation solutions must be given the time needed to dry and evaporate before the operation starts.

\section{Practice advisory (0 Fig. 5)}

1. Education: teach fire safety, with emphasis on the risk created by oxygen-enriched atmospheres.

2. Rehearsal: OR fire drills, in which a formal rehearsal with the entire OR team with simulation and training on surgical fire is conducted.

3. Preparation: scoring and discussing the fire risk.

\section{Prevention strategies}

First and foremost, it is mandatory to take precautions to prevent a surgical fire from occurring. According to the Memorial Medical Center, a fire risk assessment tool should be added to every OR checklist before a procedure starts. The tool consists of scoring the potential risk of the triad components and their interventions. An overlapping task, regardless of the components, is a team conversation in which the score is defined and channelling and tunnelling between an oxygen-rich environment and the surgical field is prevented.

The main findings of the interventions are summarized regarding their role.

1. Oxidizer intervention consists of discontinuing oxygen supplementation for at least $1 \mathrm{~min}$ prior to the use of an ignition source and titrating the oxygen concentration to the lowest concentration possible. Furthermore, considering ETT, use either cuffed for airway surgery or a laser-safe one when a laser is utilized.

2. Ignition source intervention consists of leaving the electrosurgical device in a holster $100 \%$ of the time, the laser on stand-by when not in use, and the fiber optic light source "off" when not in use. Use of an ignition source should be announced.

3. Fuel intervention consists of preventing pooling of prep solutions and allowing these solutions to dry for at least $3 \mathrm{~min}$. Furthermore, salinesoaked sponges and sterile water are needed in the field to extinguish a potential fire [33].

According to the American Society of Anesthesiologists, if the fire occurs in the airway then the tracheal tube has to be removed first, followed by turn- 


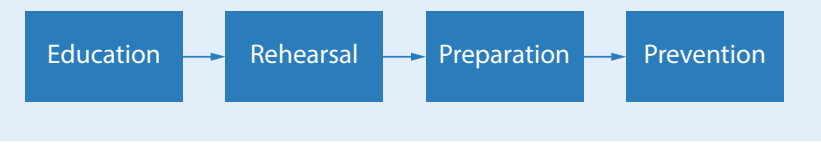

Fig. $5 \Delta$ Practice advisory, see text for details

ing off any supplementation of gases. All flammable materials should then be removed, and saline should be poured into the patient's airway. In the case of a nonairway fire, it is not necessary to remove the tracheal tube. Once the fire is extinguished, ventilation should be maintained or re-established, and in the case of an airway fire, the tracheal tube should be checked and a bronchoscopy has to be considered [3]. If the fire cannot be extinguished at the first attempt, a $\mathrm{CO}_{2}$ extinguisher should be used, followed by activating the fire alarm, evacuating the patient, closing the OR door and turning off the gas supply to the room [3]. Immediately after the patient's status is stable and the situation is under control, a record of the exact operating conditions should be taken, including oxygen flow rates, oxygen delivery methods, the ignition source, and the fuel that caught fire first.

\section{Conclusion}

Surgical fires are a rare but life-threatening complication in the OR. The real prevalence of surgical fires is uncertain. The "fire triad", consisting of an ignition source, an oxidizer and fuel, illustrates the interaction of these components and emphasizes the fatal role of an oxygen-enriched environment. Even "fire-safe" materials may be flammable or at least smouldering in oxygen-rich environments. With respect to the further prevention of this "never event", mandatory protocols should be implemented in OR safety guidelines [33]. Moreover, in the case of a fire, operational procedures to counteract the fire should be presented and trained. Finally, a standardized reporting system would increase our knowledge of potential catalysis and of the total number of surgical fires. The best method of protection is situational awareness of all team members (• Fig. 6) and, at the least, basic knowledge about

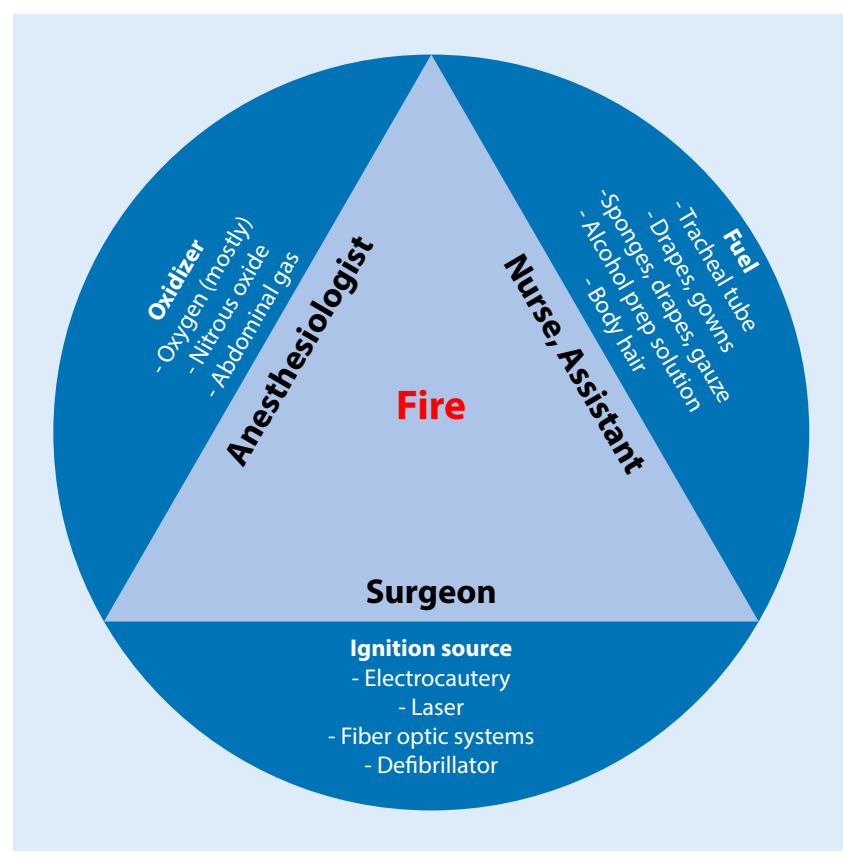

Fig. $6 \Delta$ Fire triad components regarding staff members. Modified according to $[24,56]$

the specific components in the individual setting, leading to the ignition of a surgical fire.

\section{Corresponding address}

Priv.-Doz. Dr. G. Schälte, MA

Department of Anesthesiology, University Hospital RWTH Aachen

Pauwelsstr. 30, 52074 Aachen, Germany

gschaelte@ukaachen.de

\section{Compliance with ethical guidelines}

Conflict of interest. I. Kezze, N. Zoremba, R. Rossaint, A. Rieg, M. Coburn and G. Schälte declare that they have no competing interests.

This article does not contain any studies with human participants or animals performed by any of the authors.

\section{References}

1. Hempel Set al (2015) Wrong-site surgery, retained surgical items, and surgical fires: a systematic review of surgical never events. JAMA Surg 150(8):796-805

2. Eichhorn JH, Eisenkraft JB (2013) Expired oxygen as the unappreciated issue in preventing airway fires: getting to "never". Anesth Analg. https://doi.org/ 10.1213/ANE.0b013e3182a6d34d
3. Fires R (2008) Practice advisory for the prevention and management of operating room fires. Anesthesiology 108(5):786-801

4. Watson DS (2009) Surgical fires: $100 \%$ preventable, still a problem. AORN J 90(4):589-593

5. Smith TL, Smith JM (2001) Electrosurgery in otolaryngology — head and neck surgery: principles, advances, and complications. Laryngoscope 111(5):769-780

6. Mehta SP et al (2013) Operating room fires. A closed claims analysis. J Am Dent Soc Anesthesiol 118(5):1133-1139

7. Reyes RJ et al (1995) Supplemental oxygen: ensuring its safe delivery during facial surgery. Plast Reconstr Surg 95(5):924-928

8. Huddleston $S$ et al (2013) Fire risk during ophthalmic plastic surgery. Ophthalmology 120(6):1309-1309

9. Orhan-Sungur Metal (2009) Effect of nasal cannula oxygen administration on oxygen concentration at facial and adjacent landmarks. Anaesthesia 64(5):521-526

10. Meneghetti SC et al (2007) Operating room fires: optimizing safety. Plast Reconstr Surg 120(6):1701-1708

11. Greco RJ et al (1995) Potential dangers of oxygen supplementation during facial surgery. Plast Reconstr Surg 95(6):978-984

12. Barnes AM, Frantz R (2000) Do oxygen-enriched atmospheres exist beneath surgical drapes and contribute to fire hazard potential in the operating room? AANA J68(2):153-162

13. VanCleave AM et al (2014) The effect of intraoral suction on oxygen-enriched surgical environments: a mechanism for reducing the risk of surgical fires. Anesth Prog 61(4):155-161

14. Tao JP et al (2013) The efficacy of a midfacial seal drape in reducing ocul ofacial surgical field fire risk. Ophthal Plast Reconstr Surg 29(2):109-112 
15. Wolf GL et al (2004) Laser ignition of surgical drape materials in air, $50 \%$ oxygen, and $95 \%$ oxygen. Anesthesiology 100(5):1167-1171

16. Culp WC, Kimbrough BA, Luna S (2013) Flammability of surgical drapes and materials in varying concentrations of oxygen. Anesthesiology 119(4):770-776

17. Roy S, Smith LP (2015) Prevention of airway fires: testing the safety of endotracheal tubes and surgical devices in a mechanical model. Am J Otolaryngol 36(1):63-66

18. Roy S, Smith LP (2011) What does it take to start an oropharyngeal fire? Oxygen requirements to start fires in the operating room. Int J Pediatr Otorhinolaryngol 75(2):227-230

19. Choudhry AJ et al (2017) Surgical fires and operative burns: lessons learned from a 33year review of medical litigation. Am J Surg 213(3):558-564

20. Smith LP, Roy S (2008) Fire/burn risk with electrosurgical devices and endoscopy fiberoptic cables. Am JOtolaryngol 29(3):171-176

21. Eggen MA, Brock-Utne JG (1994) Fiberoptic illumination systems can serve as a source of smoldering fires. JClin Monit 10(4):244-246

22. Williams D et al (2006) Fiberoptic light sourceinduced surgical fires - the contribution of forcedair warming blankets. Acta Anaesthesiol Scand 50(4):505-508

23. Smith LP, Roy S (2011) Operating room fires in otolaryngology: risk factors and prevention. Am J Otolaryngol 32(2):109-114

24. Rocos B, Donaldson L (2012) Alcohol skin preparation causes surgical fires. Ann R Coll Surg Engl 94(2):87-89

25. Zlochower IA, Green GM (2009) The limiting oxygen concentration and flammability limits of gases and gas mixtures. J Loss Prev Process Ind 22(4):499-505

26. McManus $N$ (1998) Safety and health in confined spaces. CRC, Boca Raton

27. Guglielmi CL et al (2014) Empowering providers to eliminate surgical fires. AORN J 100(4):412-428

28. Zeeck SC (2017) Chemie für Mediziner. Elsevier Health Sciences, München

29. Jones DB et al (2015) Safe energy use in the operating room. Curr Probl Surg 52(11):447-468

30. Wikipedia (2017) Laser. https://de.wikipedia.org/ wiki/laser

31. Culp WC Jr et al (2014) Operating room fire prevention: creating an electrosurgical unit fire safety device. Ann Surg 260(2):214-217

32. KiyoyamaTetal (2009) Isopropylalcohol compared with isopropyl alcohol plus povidone-iodine as skin preparation for prevention of blood culture contamination. JClin Microbiol 47(1):54-58

33. Memorial Medical Center, I (2011) Fire risk assessment tool. http://surgicalfireorg.fatcow.com/wpcontent/uploads/2012/10/RiskAssessmentTool. pdf. Accessed December 3, 2017

34. Stouffer D (1992) Fires during surgery: two fatal incidents in Los Angeles. J Burn Care Res 13(1):114-117

35 . Rinder CS (2008) Fire safety in the operating room Curr Opin Anaesthesiol 21(6):790-795

36. Niskanen $M$ et al (2007) Fatal inhalation injury caused by airway fire during tracheostomy. Acta Anaesthesiol Scand 51(4):509-513

37. Barker SJ, Polson JS (2001) Fire in the operating room: a case report and laboratory study. Anesth Analg 93(4):960-965

38. de Almeida CEetal (2012) Fire in the surgical center Rev Bras Anestesiol 62(3):432-438
39. Bailey MK et al (1990) Electrocautery-induced airway fire during tracheostomy. Anesth Analg 71(6):702-704

40. Haith LR Jr et al (2012) Burn center management of operating room fire injuries. J Burn Care Res 33(5):649-653

41. Errando CL et al (2005) An infrequent case of fire in the operating room during open surgery of a tracheobronchopleural fistula. J Cardiothorac Vasc Anesth 19(4):556-557

42. Kazanjian PE, Doyle AR (2007) Fires in the operating room. In: Complications in anesthesia, 2nd edn. Elsevier, Amsterdam, pp 562-566

43. Ortega RA (1998) A rare cause of fire in the operating room. Anesthesiology 89(6):1608-1608

44. Batra S, Gupta R (2008) Alcohol based surgical prep solution and the risk of fire in the operating room: a case report. Patient Saf Surg 2(1):10

45. Chestler RJ, Lemke BN (1989) Intraoperative flash fires associated with disposable cautery. Ophthal Plast Reconstr Surg 5(3):194-195

46. Akhtar $\mathrm{N}$ et al (2016) Airway fires during surgery: management and prevention. J Anaesthesiol Clin Pharmacol 32(1):109

47. Chae S-B et al (2014) Fires and burns occurring in an electrocautery after skin preparation with alcoho during a neurosurgery. J Korean Neurosurg Soc 55(4):230-233

48. KimM-Setal (2014)Electrocautery-ignited surgical field fire caused by a high oxygen level during tracheostomy. Korean J Thorac Cardiovasc Surg 47(5):491

49. Plumlee JE (1973) Operating-room flash fire from use of cautery after aerosol spray: a case report. Anesth Analg 52(2):202-203

50. Singla AK et al (2005) Surgical field fire during a repair of bronchoesophageal fistula. Anesth Analg 100(4):1062-1064

51. Dhebri A, Afify S (2002) Free gas in the peritoneal cavity: the final hazard of diathermy. Postgrad Med J78(922):496-497

52. Chung S-Hetal (2012) A patient who was burned in the operative field: a case report. Ulus Travma Acil Cerrahi Derg 18(3):274-276

53. Katz JA, Campbell L (2005) Fire during thoracotomy: a need to control the inspired oxygen concentration. Anesth Analg 101(2):612

54. Prasad $R$ et al (2006) Fires in the operating room and intensive care unit: awareness is the key to prevention. Anesth Analg 102(1):172-174

55. Thompson JW et al (1998) Fire in the operating room during tracheostomy. South Med J 91(3):243-247

56. Feldman, Ehrenwert et al (2014) Thinking outside the triangle: a new approach to prenting surgical fires. Anest Analg 118(4):704-705
Traumatische Verletzungen der Halswirbelsäule

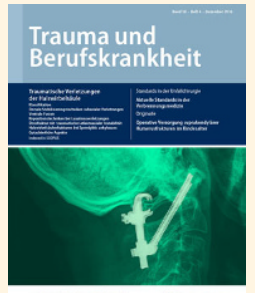

Die traumatischen Verletzungen der Halswirbelsäule umfassen neben den Verletzungen in Folge eines Hochrasanz-Traumas auch die soge-

nannten Niedrigenergie-Traumen, meist verursacht durch „einfache Stürze" älter werdender Patienten.

Das Leitthemenheft 4/2016 der Trauma und Berufskrankheit soll Ihnen einen Überblick der aktuellen operativen Therapieoptionen der häufigsten zervikalen Verletzungen geben.

Lesen Sie im Schwerpunktheft mehr zu folgenden Themen:

- Klassifikation und Gutachterliche Aspekte

- Dorsale Stabilisierungstechniken bei subaxialen Verletzungen

- Ventrale Fusion

- Repositionstechniken bei Luxationsverletzungen

- Densfraktur mit begleitender traumatischer atlantoaxialer Instabilität

- Frakturen der Halswirbelsäule bei Spondylitis ankylosans

Bestellen Sie diese Ausgabe zum Preis von 50,- EUR zzgl. Versandkosten bei Springer Customer Service Center, Kundenservice Zeitschriften

Tel.: +49 6221-345-4303

E-Mail: leserservice@springer.com

Suchen Sie noch mehr zum Thema? Mit e.Med - dem Kombi-Abo von Springer Medizin - können Sie schnell und komfortabel in über 600 medizinischen Fachzeitschriften recherchieren und auf alle Inhalte im Volltext zugreifen.

Weitere Infos unter

springermedizin.de/eMed 